\title{
MAKING JUdGES INDEPENDENT - SOME PROPOSALS REGARDING THE JUDICIARY
}

\author{
LARS P. FELD \\ STEFAN VOIGT
}

CESIFo Working PAPER No. 1260

CAtegory 2: Public Choice

August 2004 


\title{
MAKING JUdGES INDEPENDENT - SOME PROPOSALS REGARDING THE JUDICIARY
}

\begin{abstract}
It is argued that an independent judiciary is a necessary condition for both individual liberty and economic prosperity. After having surveyed the literature dealing with how to arrange for an independent judiciary, the authors derive some additional policy implications by drawing on two indicators of judicial independence (JI) recently introduced by them. De facto JI has a robust and highly significant impact on economic growth. Individual components of both de jure and de facto JI on economic growth are estimated for their impact on economic growth. Additionally, the effects of other institutional arrangements such as presidential vs. parliamentary systems are inquired into.
\end{abstract}

JEL Code: H11, K40, O40, P51.

Keywords: judicial independence, constitutional design, positive constitutional economics, economic growth.

\author{
Lars P. Feld \\ Philipps-University of Marburg \\ Public Finance Group \\ Am Plan 2 \\ 35037 Marburg (Lahn) \\ Germany \\ feld@wiwi.uni-marburg.de
}

\author{
Stefan Voigt \\ Economic Policy \\ Economics Department \\ University of Kassel \\ Nora-Platiel-Str. 4-6 \\ 34109 Kassel \\ Germany \\ voigt@wirtschaft.uni-kassel.de
}

The authors would like to thank the participants of the SNS Conference on Constitutional Design, in particular Roger Congleton and Torsten Persson, for stimulating suggestions; the support of the Gesellschaft für technische Zusammenarbeit (GTZ) in collecting data is gratefully acknowledged. 


\section{$1 \quad$ Introduction}

The judiciary has frequently been called "the least dangerous branch" (e.g. Hamilton 1787/1961, Federalist Paper \#78). This evaluation might be one reason why the judiciary is rarely moved to center stage during discussions concerning issues of constitutional design. To give just one example: in his treatise on "Comparative Constitutional Engineering", Sartori (1994) deals extensively with electoral systems (majoritarian vs. proportional) as well as with the modus of electing the executive (presidential vs. parliamentary systems) but the term " $\mathrm{ju}$ diciary" does not even appear in the index.

It has, however, been hypothesized that judicial independence (JI) is one central aspect in the proper functioning of the judiciary as part of the concept of separation of powers as it has been developed by Montesquieu and further concretized by Hamilton, Madison, and Jay, the authors of the Federalist Papers. Feld and Voigt (2003) have recently presented two indicators that aim at making judicial independence measurable. Their first indicator deals with de jure independence, i.e. the independence of the courts as it can be deduced from legal documents. Their second indicator deals with de facto independence, i.e. the degree of independence that the courts factually enjoy. Estimating the impact of JI on economic growth, Feld and Voigt (2003) find that while de jure JI does not have an impact on economic growth, de facto JI positively influences real GDP per capita growth in a sample of 56 countries. The impact of de facto $\mathrm{JI}$ on economic growth is robust to outliers, to the inclusion of several additional economic, legal and political control variables and to the construction of the index. The authors thus conclude that judicial independence matters for economic growth.

If JI matters for growth, economists will be ready to rethink its role when discussing issues of constitutional design. Accordingly, the main question of this paper is to ask what components of de jure and de facto JI are particularly conducive to economic growth and how they interact with the constitutional and legal environment in the different countries. ${ }^{1}$ This investigation is based on a cross section of 73 countries extending the Feld and Voigt (2003) data set. In a first step, we replicate the result of the former paper - namely that JI matters for economic growth - for the extended data set. In a second step, we inquire into the effects of the organizational structure of the judiciary. In a third step it is asked whether institutional arrangements that are not part of the judiciary themselves have an impact on economic growth and whether there is an interaction of other constitutional and legal provisions with JI. We find

1 The World Bank has been involved in a number of programs dealing with similar, yet not identical goals: whereas our interest focuses on the independence of the judiciary from the other two government branches, the World Bank has often put emphasis on the efficiency of the court system. Dakolias (1999) has explained that efficiency-enhancing measures within the judiciary can be kicked off without having to wait for the consent of the other government branches. A more recent description of the World Bank's activities can be found in a recent edition of the World Development Report (2002, especially chapter 7). 
that de facto JI has a robust and highly significant positive impact on economic growth. Looking at the components of de jure JI, the specification of the procedures, of the accessibility and of the term length of highest court judges in the constitution show a modestly significant positive impact on economic growth, while a wide accessibility of the highest court as well as the highest court's power for constitutional review are negatively affecting economic growth. The other components of de jure JI do not appear to have an impact. With respect to de facto JI, no deviations from 'normal' average term length, low numbers of changes of the number of judges since 1960 and a competitive income of judges are the main factors influencing growth. With regard to the impact of the organizational structure of the courts on economic growth, we find no significant differences between courts organized as constitutional courts and courts organized differently. Concerning the additional constitutional and legal environment, our results indicate that the positive impact of de facto JI on economic growth is stronger in presidential than in parliamentary systems as well as in systems with a high extent of checks and balances. De facto JI appears to be effective independent of the age of a constitution. On the contrary, if a state is able to implement de facto JI, countries with older constitutions have a slight, but significant growth disadvantage.

To non-economists, the approach taken in this paper might appear very odd: according to many, the primary function of the judiciary would be to enhance justice, fairness, or equity. Yet, these goals do not necessarily conflict with economic growth. If the degree to which these other goals are realized can be kept constant and different institutional arrangements promise different levels of growth or per capita income, it makes sense to argue in favor of the implementation of those institutional arrangements that are most conducive to economic growth. In this paper, we are concerned with the economic consequences of institutional choices regarding the judiciary broadly conceived. It is thus a positive paper. As long as the underlying goal - economic growth - is shared, it can easily be turned into constitutional advice. The choice of institutional arrangements itself will, however, not be endogenized. We are thus not concerned with possible reasons of constitution-makers to choose different institutional arrangements with regard to the judiciary (for this question, see Landes and Posner 1975, Ramseyer 1994, and Ginsburg 2002).

The remainder of the paper is organized as follows: in the next section, there will be a short review of the existing literature, section 3 presents a number of hypotheses concerning the effects of JI, judicial structure and the structure of state organization on economic growth, the fourth section contains the description of our data set as well as own estimations. In section 5, some preliminary conclusions regarding constitutional design are drawn, and section 6 concludes. 


\section{Survey of the Literature}

The focus of this paper is on constitutional design, i.e. on propositions how the constitution should be designed in order to reach some goals or values. We simply assume that the goal is a high growth rate of per capita income. We will thus not enter into any normative discourse about constitutional or societal goals. We conjecture - and set out to test - that judicial independence is conducive to economic growth. If this can be shown, we consider this as sufficient reason to establish an independent judiciary at the constitution-making stage (other normative arguments in favor of an independent judiciary will thus not be developed; for a contractarian argument in favor of JI, see, e.g., Congleton 2003). In addition, as Persson and Tabellini (2003) show, other constitutional arrangements such as the degree of checks and balances might - jointly with JI - also have an impact on economic growth, which is why we test for interaction effects. A diagrammatic description of the impact of judicial independence on economic growth can be found in Figure 1. In a sense, JI is here both a dependent and an independent variable: once the constitutional convention has made its choice, JI can be used as an independent variable to explain economic growth. But if the analysis of the choices of the constitutional convention were the target, JI would rather be a dependent variable. There have been attempts to deal with the judiciary from both angles.

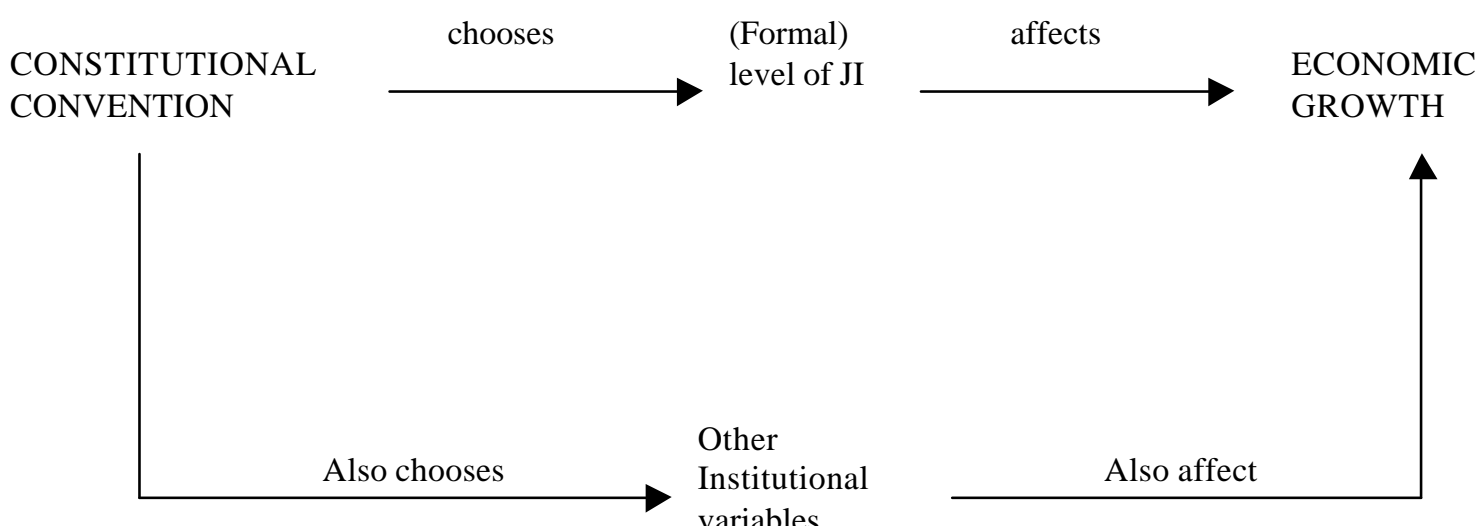

Judicial independence has been analyzed as the amount of discretion that judges have at their disposal vis-à-vis representatives of other government branches by a research program dubbed positive political theory (surveyed by Weingast 1996). Papers originating from that program are usually based on spatial voting models that identify the ideal points of all relevant actors in issue space. ${ }^{2}$ The amount of discretion that the judiciary has at its disposal depends on the exact location of the ideal points of the other actors. If it anticipates their loca-

2 There are models on judicial discretion in statutory interpretation (e.g. Ferejohn and Weingast 1992) and on the reactions of the legislature (e.g. Gely and Spiller 1990). Others have analyzed the relationship between Congress and bureaucracy extensively (McCubbins and Schwartz 1984, McCubbins, Noll, Weingast 1987, 1989; Moe 1990; Macey 1992; Zeppos 1993). There is plenty of institutional detail in these models. This, however, is also one of their weaknesses as they are almost exclusively focus on the U.S. 
tions correctly, it can make a decision that maximizes its own utility subject to the relevant constraints, i.e. (i) the danger of being overridden by fresh legislation that would be passed through the legislature or (ii) by having its dicta ignored by the executive. These models particularly focus on the power game played between representatives of the various government branches. The degree of independence is not completely determined by institutional provisions (such as the number of chambers needed to press fresh legislation, required supermajorities etc.) but also by the current preferences of those politicians currently holding office. This is why empirical studies based on that approach have focused on the change of the level of judicial independence within a single country over time (Chavez, Ferejohn and Weingast 2003 apply the approach to the U.S. and to Argentina over long periods of time). Using these models empirically is, however, a very tricky business as the relevant dimensions of many issues are everything but obvious and the ideal points of many actors difficult to identify.

In her paper on "the budget as a signaling device", Toma (1991) has analyzed one channel through which the other branches can communicate their (dis-)content with the decisions of the Supreme Court, namely by increasing or decreasing the Court budget. Judicial independence can here be interpreted to be the dependent variable as the functioning of the Court depends on the budget it can spend. Hanssen (2002) has recently tested two predictions first generated by Ramseyer (1994), namely that judicial independence will be higher (i) if politicians fear to lose power and (ii) the farther the ideal points of the rival parties are apart. Using judicial retention procedures as the proxy for judicial independence, he finds empirical support for these hypotheses in his analysis of panel data covering the U.S.-states between 1950 and 1990. In a number of papers, Ramseyer and Rasmusen have investigated the independence of the Japanese judiciary. Using personnel data on 276 judges, Ramseyer and Rasmusen (1997) present evidence that judges who decided a case against the government incurred the risk of being punished with less attractive posts. Ramseyer and Rasmusen (1999) extend that analysis by showing that Japanese judges who decide cases in favor of the government do better than those who favor taxpayers in two samples of 179 tax trial and 284 tax appeal cases. Obviously, judicial independence is endangered if the government is solely responsible for career developments of judges. This should particularly hold with respect to judges' reelection possibilities. With new and more detailed data, Ramseyer and Rasmusen (2001a) find however evidence that judges who enjoin the national government jeopardize their career: Judges who enjoined the national government received fewer administrative responsibilities. Finally, Ramseyer and Rasmusen (2001b) provide evidence for the hypothesis that the high Japanese conviction rates (over 99 percent) reflect case selection and low prosecutorial budgets instead of any pro-conviction bias at the judicial administrative office.

Besley and Payne (2003) have recently used a similar approach to explain differences in judicial behavior: they find that judges bring about decisions which favor important parts of the electorate as this might increase their chances of being re-elected. Differences in the institu- 
tional arrangements of JI are used to explain differences in judicial decision-making. This is thus a study in which JI is the independent variable. La Porta, López-de-Silanes, Pop-Eleches, and Shleifer (2003) have recently come up with a measure for JI distinguishing an English from an American concept and have found that the English concept is a good predictor for economic freedom whereas the American one is a good predictor for political freedom. Yet, they have not tried to distinguish between JI as it is written in the books and as it is factually implemented. Neither of these two papers estimates the effects of JI on economic growth.

Figure 1 indicates that it might also be useful to think about possible impacts of other institutional variables such as the separation of powers on economic growth. That the separation of powers serves to constrain government and to make citizens better off has been a commonplace for a long time. Yet, its economic analysis has only begun recently. Brennan and Hamlin (1994) observe that a strict separation of powers - as opposed to checks and balances, where the various branches check each other - can make citizens even worse off. Persson, Roland, and Tabellini (1997) find that the separation of powers can increase accountability of politicians vis-à-vis citizens. They also find that presidential systems can have an advantage over parliamentary ones with regard to accountability: this is the case if the president is elected directly, but the executive in parliamentary systems does not have to step down when there are legislative elections. In that case, there is an incentive for the two branches to collude, which would enable the executive to realize rents even after election day.

Both of these models deal with the relationship between executive, legislature and voters. In neither of them is the judiciary modeled as another agent that functions as a constraint on the executive or the legislature. Padovano, Sgarra, and Fiorino (2003) is an extension of the Persson et al. model that incorporates the judiciary as a fourth actor. They find that an independent judiciary improves accountability but that this is not the case for an accommodating judiciary. They conjecture that the likelihood that the three branches will collude (and that accountability will suffer) depends on the term-lengths of the three branches. With regard to the judiciary, they expect longer term lengths to lead to lower accountability - and less welfare.

Yet another way to approach the judiciary is to view it as a technical institution to which a limited range of competence is delegated. Although the rational choice analysis of delegation has recently boomed (see, e.g., Majone 1996 or Epstein and O'Halloran 1999, Voigt and Salzberger 2002 is an overview), path-breaking theoretical insights concerning the judiciary have not yet emerged. In a paper concerned with the accountability of both politicians and judges, Maskin and Tirole (2001) confirm conventional wisdom that technical issues are ill suited for the political process and that non-accountable officials should be given less discretion than their elected counterparts.

Although research into causes and effects of the judiciary are of rather recent vintage, constitution-makers have, of course, always dealt with the issue. The locus classicus for issues $1 \mathrm{e}-$ 
garding the institutional structure of the judiciary is still the Federalist Papers. Federalist papers 78 and 79, both penned by Hamilton, contain a number of institutional provisions that are to safeguard the independence of the (federal) judges. In Federalist 78, Hamilton argues for life-tenure, discusses the competence of nominating and appointing judges and makes a point in favor of giving the courts the competence of judicial review. ${ }^{3}$ Mueller (1996) has recently reiterated that point stressing that the competence of judicial review is logically necessary if the judiciary is to safeguard citizens from the other government branches. In Federalist 79, Hamilton pleads in favor of guaranteeing judges a non-decreasable income and of introducing a highly regulated - and thus difficult to misuse - impeachment procedure.

It is interesting to note that Mueller (1996) does not think that the institutional structure is sufficient to ensure a judiciary that is not only independent but also accountable to its principals, namely the citizens: "For these, one has to rely on the 'culture of the judiciary' and the great status (and possibly financial rewards) that surround it." This could mean that formal constitutional rules might not be sufficient to ensure an independent judiciary.

\section{Hypotheses on the Relationship Between Judicial Independence and Economic Growth}

\subsection{A Very General Argument}

JI implies that judges can expect their decisions to be implemented regardless of whether they are in the (short-term) interest of other government branches upon which implementation depends. It further implies that judges - apart from their decisions not being implemented - do not have to anticipate negative consequences as the result of their decisions, such as (a) being expelled, (b) being paid less, or (c) being made less influential. Three archetypical situations in which the independent judiciary plays a crucial role can be distinguished:

(1) In cases of conflict between private parties: If they had voluntarily entered into a contract and one of the contracting parties believes that the other side hasn't lived up to the contract, impartial dispute resolution can be important. As long as both sides expect the judiciary to be impartial and hence independent from pressure emanating from either of the contract partners or any other party, they can save on transaction costs while negotiating their contract. On average, lower transaction costs will lead to more welfare-enhancing transactions taking place.

(2) In cases of conflict between government and the citizens, the citizens are in need of an organization that can adjudicate who is right (who has acted according to the law). The judici-

3 On appointment, see also Federalist Paper 51 written by James Madison: "In order to lay a due foundation for that separate and distinct exercise of the different powers of government, ..., it is evident that each department should have a will of its own; and consequently should be so constituted that the members of each should have as little agency as possible in the appointment of the members of the others." 
ary performs this task. This does not only mean to ascertain the constitutionality of newly passed legislation but also to check whether the representatives of the state have followed the procedural devices that are to safeguard the rule of law. The judiciary helps to ensure that the government is under the rule of law.

(3) In cases of conflict between various government branches. In the absence of an impartial arbiter, conflicts between government branches are most likely to develop into simple power games. An independent judiciary can keep them within the rules laid out in the constitution.

Among the many functions of government, the reduction of uncertainty is of paramount importance. But the law will only reduce uncertainty if the citizens can expect the letter of the law to be followed by government representatives. An independent judiciary could thus also be interpreted as a device to turn promises into credible commitments - e.g. to respect property rights and abstain from expropriation. If it functions like this, citizens will develop a longer time horizon which will lead to more investment in physical capital but also to a higher degree of specialization, i.e., to a different structure of human capital. All this means that JI is expected to be conducive to economic growth.

\subsection{Constitutional Provisions to Safeguard Judicial Independence}

Assume that JI does indeed induce economic growth, how could constitutional provisions safeguard it? The independence of judges is dependent upon the stability of the set of constitutional provisions within which they operate. Formally, the stability of the powers and procedures of the court depend on how difficult it is to change them. If they are specified in the constitution itself, we expect a greater degree of independence than if they are simply fixed by ordinary law. This presupposes that constitutional law is more difficult to change than ordinary legislation.

The appointment procedure of the judges may have a notable effect on the independence of the court. As it is inter alia supposed to protect citizens from illegitimate use of powers by the other government branches as well as to settle disputes between the branches of government, it ought to be as independent as possible from the other branches. We hypothesize that the most independent procedure for judicial appointment is by professionals (other judges or jurists). ${ }^{4}$ The least independent method is appointment by one powerful politician (prime minister or a minister of justice, e.g.).

4 In Federalist Paper 51, James Madison (Hamilton, Madison, and Jay 1788/1961, 321) writes: "In order to lay a due foundation for that separate and distinct exercise of the different powers of government, ..., it is evident that each department should have a will of its own; and consequently should be so constituted that the members of each should have as little agency as possible in the appointment of the members of the others." - On the same topic, Hamilton writes (Hamilton, Madison, and Jay 1788/1961, 470f.): “That inflexible 
Judicial tenure will be crucial for the independence of the judiciary. We assume that judges are most independent if they are appointed for life (or up to a mandatory retirement age) and cannot be removed from office, save by legal procedure. Judges are less independent if terms are renewable because they have an incentive to please those who can reappoint them.

Further, if their salaries are determined by the members of one of the other government branches, this raises incentives to take the preferences of these members explicitly into account. General rules that their salary cannot be reduced increase, in turn, the independence of the judiciary.

Another component of judicial independence is the accessibility of the Court and its ability to initiate proceedings. A court, which is accessible only by a certain number of members of parliament or other officials, will be less effective in constraining government vis-à-vis its citizens than a court, which is accessible by every citizen who claims that her rights are violated.

If the allocation of cases to the various members of the court is at the discretion of the chief justice, his influence will be substantially greater than that of the other members of the court. It follows that in such an institutional environment, it could be interesting to try to "buy" just the chief justice. We expect independence to be larger if there is a general rule according to which cases are allocated the responsibility of single members of the court (Salzberger 1993).

The competencies assigned to the constitutional court do not bear directly on its independence. Yet, highest courts must have certain competencies in order to be able to check the behavior of the other government branches. If the constitution is interpreted as the most basic formal layer of rules that is to restrain (and to enable) government, then the competence of the court to check whether legislation is in conformity with the constitution is crucial. This is also known as the competence to constitutional or judicial review.

If courts have to publish their decisions, others can scrutinize them and the reasoning can become subject to public debate. This can be interpreted as making it more difficult for representatives of the other government branches to have irrelevant considerations influence their decisions. The transparency will be even higher if the courts publish dissenting opinions.

and uniform adherence to the rights of the Constitution, and of individuals, which we perceive to be indispensable in the courts of justice, can certainly not be expected from judges who hold their offices by a temporary commission. Periodical appointments, however regulated, or by whomever made, would, in some way or other, be fatal to their necessary independence. If the power of making them was committed either to the executive or legislature there would be danger of an improper complaisance to the branch which possessed it; if to both, there would be an unwillingness to hazard the displeasure of either; if to the people, or to persons chosen by them for the special purpose, there would be too great a disposition to consult popularity to justify a reliance that nothing would be consulted by the Constitution and the laws." 
All these issues can be taken up by corresponding constitutional provisions. In order to find out whether these have indeed the expected effect on economic growth, we will test for their respective impact in section 4 .

\subsection{Organizational Structure of the Judiciary}

The variables discussed in the last section were all conjectured to be part of judicial independence. There are a number of potentially relevant variables that might also determine the capacity of the judiciary to act as a constraint upon the other government branches. If a strong and independent judiciary enhances economic growth, then the issues of judicial organization and structure can be conjectured to have an indirect effect on growth. There are various possibilities to design constitutional review: (i) it can be allocated to each and every court of a country as in the U.S.; there is thus no specialized court. This implies that constitutional eview is a posteriori, and the uniformity of jurisdiction is secured by the highest court of the country (in the U.S. the Supreme Court). (ii) The Austrian model as proposed by Hans Kelsen (1920) in which a specialized constitutional court deals with constitutional matters. It can entail both abstract and concrete review, as well as ex ante and ex post review. (iii) The French model in which constitutional matters are dealt with by a special body (e.g. the Conseil Constitutionnel in France) that is constrained to ex ante review (Harutyunayn and Mavcic 1999). ${ }^{5}$

There is no clear-cut hypothesis concerning the effects of the various systems. It could, however, be argued that judicial influence is broadest where the judiciary has the competence to check upon the constitutionality of laws both ex ante and ex post and where constitutional review can be both abstract and concrete. In the U.S.-model, constitutional review is restricted to ex post and concrete review. Formal competencies of judiciaries organized along the lines of the Austrian model are often broader since they can also encompass ex ante and abstract constitutional review. The French model is more restricted from the other side of the spectrum: there, constitutional review is only possible before a law has come into force. If laws are only recognized to be incompatible with the constitution after they have been in force for a while, there is nothing much that the Conseil Constitutionnel can do. On the grounds of the formal capacity of the judiciary to keep the other two branches within the limits spelled out in the constitution, we would thus expect the Austrian model to have some advantages over the U.S. as well as the French system. Between these two, the French seems to be the one conferring least competence to the judiciary.

5 Most, but not all, constitutional systems can be grouped into one of the three models presented. Additionally, Harutyanayn and Mavcic (1999) name a "New (British) Commonwealth Model" implemented by Mauritius, and a "Mixed (American Continental) Model" which can be found in a number of states, inter alia in Portugal, Columbia, Ecuador, Guatemala, and Peru. 


\subsection{Effects of Constitutional Provisions Not Dealing with the Judiciary}

Constitutional provisions not directly dealing with the judiciary may, nevertheless, have an impact on the influence of the judiciary. If the system of checks and balances puts tight constraints on the executive and the legislature, this might translate into relatively more influence of the judiciary. Henisz (2000) has proposed an indicator for measuring the degree of checks and balances that is based on the number of veto players found in a political system. Beck et al. (2000) have proposed a similar measure on which we concentrate here.

Closely related to the number of veto players is the question of whether one is dealing with a parliamentary or a presidential system. True, this issue is primarily concerned with the relationship between executive and legislature. But if the members of these two government branches have incentives to collude, the relevance of the judiciary might be different from an organization where executive and legislature have incentives to check on each other. Presidential systems are characterized by a more stringent separation of powers. This could lead one to conjecture that the role of the judiciary should be more important in presidential systems. Yet, there are a number of counter-arguments: the impact of the judiciary does not depend on the legal provisions alone, it depends much more on the ways they are factually enforced. Factual judicial independence is a result of the incentives of the members of the other government branches not to comply with rules regarding the treatment of the judiciary as laid down in the constitution. It will therefore be asked whether the incentives to renege on the relevant constitutional rules depend on the issue whether one is dealing with a presidential or a parliamentary system.

Presidents often claim that they are the only ones who represent the people as a whole. ${ }^{7}$ This might make them more audacious than, e.g., prime ministers in reneging upon constitutional constraints. Political parties are regularly weaker in presidential than in parliamentary systems. This might further increase the incentives of presidents not to take formal judicial independence too seriously: if parties are weak, the possibility to produce opposition against a president who reneges upon the constitution might be less than in systems with strong political parties. A reduced likelihood of opposition does, of course, make reneging upon constitutional rules more beneficial. There might be yet another transmission mechanism concerned with political parties. Brennan and Kliemt (1994) show that organizations like political parties

6 Keefer and Stasavage (2003) find that the estimations of inflation rates based on (de jure) central bank independence significantly improve if the number of veto players is controlled for.

7 De Gaulle declared in 1964 ,that the indivisible authority of the State is entrusted completely to the president by the people who elected him, that there existed no other authority, either ministerial, civil, military or judiciary which has not been conferred and was not being maintained by him, and finally that it was his duty to adapt the supreme domain, which is his alone, to fit in with those, the control of which he delegates to others." (quoted according to Duverger 1980). Although this quote surely is illustrative it might, admittedly, not be representative of presidents. 
often develop longer time horizons than individual politicians: whereas presidents will be out after one or two terms (as in Mexico or the U.S.), political parties might opt for staying in power indefinitely (like in Japan). If the discount rate of presidents is indeed higher than that of, say, prime ministers or party leaders, this might also let offenses against judicial independence appear more beneficial to presidents than to prime ministers. We include a variable here that distinguishes between presidential and parliamentary systems based on the Database on Political Institutions (DPI), which was provided by Beck et al. (2000).

A third possible determinant, also closely related to the first one, is the question of whether one is dealing with a unitary or a federal system. Federal systems have a larger number of veto players than unitary ones and we would c.p. expect a higher degree of de facto JI in federal than in unitary states. Unfortunately, it is notoriously difficult to "measure" the degree of federalism of a given political system. Treisman (2000) contains a dummy variable on federalism, which is based on Elazar (1995) and Riker (1964). This variable is used here.

Yet another aspect of the issue of veto players is concerned with the possibility to constrain the judiciary itself. If the judiciary has the competence to constrain the legislature and the executive but nobody has the (legal) competence to constrain the judiciary, its members might have incentives to become overly active, overly passive or follow their own agenda, whatever that may be. This danger was precisely described by Brutus in the Anti-Federalist Paper \#11: "It is, moreover, of great importance, to examine with care the nature and extent of the judicial power, because those who are to be vested with it, are to be placed in a situation altogether unprecedented in a free country. They are to be rendered totally independent, both of the people and the legislature ...No errors they may commit can be corrected by any power above them ... nor can they be removed from office for making ever so many erroneous adjudications." There might, however, be a possible constitutional constraint to judicial behavior, namely the possibility of the population at large to check upon the actions of the judicial branch. Hayek $(1960,192)$ had seen this very clearly: "the practice of restraining government's pursuit of immediate aims by general principles is partly a precaution against drift; for this, judicial review requires as its complement the normal use of something like the referendum, an appeal to the people at large, to decide on the question of general principle." It could thus be hypothesized that the possibility of a referendum acts upon a constraint on the judiciary that will make it more accountable. ${ }^{8}$ Whether this induces indeed additional growth cannot be tested due to the lack of internationally comparable data. However, it is kept in mind for future research.

8 It should be added that the possibility of referenda also acts as an additional constraint on the other two government branches and against collusion between them. See e.g. the paper by Frey and Stutzer in this volume and the references quoted there. 
In addition to these various aspects of checks and balances that are all conjectured to influence the position of the judiciary vis-à-vis the other branches, possible consequences of the design of basic rights might also shape the impact of an independent judiciary. The basic right of freedom of expression entails the right to a free press. A free press is hypothesized to be conducive to a high degree of de facto JI. Strictly speaking, a free press is not part of the relevant institutional structure, but rather a consequence of a certain institutional structure. If politicians consider tinkering with the independence of the judiciary, a press that is largely free from government interference can make such attempts costly - and hence less attractive for politicians by widely reporting them. At times, a free press can be instrumental for helping those opposed to the interference into the independence of the judiciary to overcome their collective action problems. The indicator used here is provided by Freedom House on an annual basis and takes into account aspects such as whether or not dissent is allowed, whether there is political pressure on the content of the media no matter whether state run or privately owned, whether there is economic influence on media content that would distort the quality of reporting, and whether there have been any incidents in which press freedom was violated such as murders, arrests, suspension and the like.

\section{Data Description, Estimation Approach and Results}

Recently, two new indicators measuring de jure as well as de facto JI have been presented (Feld and Voigt 2003). For simplicity reasons, these indicators measure the independence of the highest court of a country, no matter whether it is a supreme court or a constitutional court. In many states, the judiciary is made up of thousands of decision-makers and, therefore, radical simplification is necessary. The focus on the highest court seems warranted because even though judges are personally independent, the ultimate control of court decisions lies with the highest courts, as they review - on the initiative of the parties involved - the lower court decisions. The independence of the highest court thus seems crucial.

Secondly, these indicators are constructed as objective as opposed to subjective indicators. A subjective indicator of JI would ask for the perception of independence amongst those being polled. For those who live under the respective rules, their perception is surely an important element determining their behavior. However, the norms of what an ideally independent judiciary would look like will most likely be different in different parts of the world. Data obtained by polls are thus not easily comparable. The two new indicators are therefore based on factual information. In principle, anybody re-estimating JI in the countries covered should end up with the same data.

The indicator measuring de jure JI contains sixteen variables, the indicator measuring de facto $\mathrm{JI}$ ten. The de jure indicator is made up of the variables already described in section 3.2 above and thus includes the modus of nominating or appointing highest judges, their term lengths, 
the possibility of re-appointment, the procedure of removing them from office, their pay and possible measures against reduction of their income, the accessibility of the court, the question of whether there is a general rule allocating cases to specific judges, and publication requirements concerning the decisions of the court. The de facto indicator includes variables such as the effective average term lengths, the number of times judges have been removed from office since 1960, the question of whether their income has remained at least constant in real terms since 1960, the question of whether the size of the budget of the court has remained at least constant in real terms since 1960, the number of cases in which the relevant articles of the constitution were changed as well as the number of times in which other government branches remained inactive when their action was necessary in order to implement a court ruling. ${ }^{9}$ All variables can take on values between 0 and 1 . The sum of the variables is then divided by the number of variables for which information is available. One thus ends up with two variables (de jure and de facto JI) that lie between 0 and 1. By now, data are available for about 80 countries (the data can be obtained by the authors upon request).

The estimation approach is straightforward and follows the method used in modern empirical growth studies like, e.g., in the paper by de Haan and Sturm (2000). According to this approach the following equation is estimated:

$$
\Delta Y_{i}=\alpha M_{i}+\beta J I_{i}+\gamma Z_{i}+\varepsilon_{i}
$$

where $\Delta Y_{i}$ is average real GDP growth per capita of country i between the years 1980 and $1998, M_{i}$ is a vector of standard explanatory variables of country $\mathrm{i}, J I_{i}$ are the de jure and de facto indicators of judicial independence in country $\mathrm{i}, Z_{i}$ is a vector of additional explanatory variables in country $i$ that are introduced to check the robustness of the baseline model and to consider the interaction with the constitutional, legal and political environment of a country, and $\varepsilon_{i}$ is an error term.

Average real GDP growth per capita is obtained from the new Penn World Tables Version 6.0 (Heston, Summers and Aten, 2001). The data set poses particular problems with respect to Eastern European countries. Since the data of these countries in the nineties are not comparable to data in the eighties or do even not exist for the eighties because there are some newly created states, real GDP growth per capita had to be averaged for these countries depending on the first date GDP data were available instead of averaging it for the time period 1980 to 1998. ${ }^{10}$ In order to ensure that the Eastern European countries do not drive the results, a

9 For a more detailed list of the different components of these indicators, see the appendix in Feld and Voigt (2003). Any questions concerning the data can be addressed to the authors.

10 Real GDP growth per capita is averaged in the following way: Slovak Republic 1987 to 1998, Ukraine 1989, 1998, Czech Republic and Slovenia 1990 to 1998, Bulgaria and Russia 1991 to 1998, Armenia and Estonia 1992 to 1998, Lithuania 1993 to 1998, Azerbaijan and Kazakhstan 1994 to 1998, Croatia 1995 to 1998 and Georgia 1996 to 1998. Real GDP growth per capita thus reflects less and less the long run growth 
dummy variable is introduced that takes on the value of one if the country is a transition country and is zero otherwise. The vector $M_{i}$ consists of three variables, which are robustly linked to economic growth according to previous studies (de Haan and Sturm, 2000). These variables are the level of initial real GDP per capita (in our sample, 'initial' is 1980), investment in percent of GDP averaged over the period 1980 to 1998, and the percentage of secondary school attained in the total population aged 15 and older in 1980. With the exception of the latter variable, which is from the Barro and Lee data set, these data are from the PWT 6.0.

The additional economic variables making up for the vector $Z_{i}$ are average government consumption in percent of GDP between 1980 and 1996, openness measured by the sum of exports and imports in percent of GDP, average population growth between 1980 and 1998, and the average inflation rate, all from the PWT 6.0 data set. The reason for an inclusion of these variables for testing robustness of the impact of judicial independence stems from a whole bunch of empirical growth studies. Moreover, we use continent dummies to check for robus tness of the estimation results. In addition to these standard additional variables, the data by La Porta et al. (1999) on the legal origin of countries are used to test robustness of the growth impact of JI to the legal and political environment. Finally, a number of additional constitutional, legal and political variables are included, such as the age of the constitution, whether the court system follows the Austrian model or not, the extent of checks and balances in the constitution and the distinction between presidential and parliamentary systems the latter both based on the Database on Political Institutions (DPI) which was provided by Beck et al. (2000), a dummy variable on federalism reported by Treisman (2000), and an indicator for a free press provided by Freedom House.

The empirical strategy is following the lines of the underlying model. First, the baseline regressions are performed adding the two JI indicators in turn. In a second step, the additional economic variables and continent dummies are included in the regression in order to check the robustness of the results. In a third step, the JI indices are differentiated into their single components. Fourth, the additional constitutional, legal and political variables are included in the regression and are interacted with de facto $\mathrm{JI}$ in order to investigate the differential effects. We present only a selection of robustness checks in order to keep the paper still readable. Several further variations of these regressions are not reported here which were also performed in order to check robustness. The cross section analysis is performed by the simple

rate that is supposed to be measured according to the underlying growth theory. This is particularly problematic in the case of Georgia. The structural shift between West German and Unified German growth data is coped with in the following way: First, the average growth rate of GDP is computed for the period 1980 to 1990 for West Germany. Second, we compute the average growth rate of GDP for the period 1990 to 1998 for Unified Germany. Third, we take the mean of both rates. 
OLS technique while inference is based on t-statistics computed on the basis of White heteroscedasticity consistent standard errors.

Table 1: OLS-Regressions of GDP Growth per Capita from 1980 to 1998 on Judicial Independence and Controls, Baseline Specifications

\begin{tabular}{|c|c|c|c|c|c|c|}
\hline Variables & (1) & (2) & (3) & (4) & (5) & (6) \\
\hline $\begin{array}{l}\text { De jure Judicial Independ- } \\
\text { ence }\end{array}$ & - & $\begin{array}{l}0.635 \\
(0.42)\end{array}$ & - & $\begin{array}{l}-0.463 \\
(0.29)\end{array}$ & $\begin{array}{l}0.081 \\
(0.05)\end{array}$ & $\begin{array}{l}0.280 \\
(0.18)\end{array}$ \\
\hline $\begin{array}{l}\text { De facto Judicial Independ- } \\
\text { ence }\end{array}$ & - & - & $\begin{array}{c}1.885 * * \\
(3.20)\end{array}$ & $\begin{array}{l}1.914 * * \\
(3.08)\end{array}$ & $\begin{array}{l}1.511^{*} \\
(2.34)\end{array}$ & $\begin{array}{l}1.673 * \\
(2.49)\end{array}$ \\
\hline $\begin{array}{l}\text { Real GDP per capita in } \\
\left.1980 \text { (in } \$ 1^{\prime} 000\right)\end{array}$ & $\begin{array}{c}-0.177 * * \\
(4.04)\end{array}$ & $\begin{array}{c}-0.180 * * \\
(4.06)\end{array}$ & $\begin{array}{c}-0.200 * * \\
(4.19)\end{array}$ & $\begin{array}{c}-0.200 * * \\
(4.15)\end{array}$ & $\begin{array}{l}-0.205^{* *} \\
(3.42)\end{array}$ & $\begin{array}{c}-0.264 * * \\
(4.40)\end{array}$ \\
\hline $\begin{array}{l}\text { Secondary School Attain- } \\
\text { ment Rate in } 1980 \text { (in \%) }\end{array}$ & $\begin{array}{l}0.047^{*} \\
(2.47)\end{array}$ & $\begin{array}{l}0.048^{*} \\
(2.48)\end{array}$ & $\begin{array}{c}0.037(*) \\
(1.95)\end{array}$ & $\begin{array}{c}0.036(*) \\
(1.84)\end{array}$ & $\begin{array}{l}0.032 \\
(1.58)\end{array}$ & $\begin{array}{c}0.037(*) \\
(1.74)\end{array}$ \\
\hline $\begin{array}{l}\text { Real Gross Domestic In- } \\
\text { vestment (in \% of GDP), } \\
\text { Average in 1980-1998 }\end{array}$ & $\begin{array}{l}0.170 * * \\
(5.63)\end{array}$ & $\begin{array}{c}0.169 * * \\
(5.61)\end{array}$ & $\begin{array}{c}0.178 * * \\
(6.81)\end{array}$ & $\begin{array}{l}0.180^{* *} \\
(7.04)\end{array}$ & $\begin{array}{c}0.159 * * \\
(5.43)\end{array}$ & $\begin{array}{l}0.144 * * \\
(3.63)\end{array}$ \\
\hline $\begin{array}{l}\text { Dummy for Transition } \\
\text { Countries }\end{array}$ & $\begin{array}{l}-1.805^{*} \\
(2.19)\end{array}$ & $\begin{array}{c}-1.798^{*} \\
(2.19)\end{array}$ & $\begin{array}{l}-1.085 \\
(1.23)\end{array}$ & $\begin{array}{l}-1.065 \\
(1.20)\end{array}$ & $\begin{array}{c}-1.549(*) \\
(1.70)\end{array}$ & $\begin{array}{l}-2.202 * \\
(2.14)\end{array}$ \\
\hline Dummy for Africa & - & - & - & - & $\begin{array}{l}-0.890 \\
(1.30)\end{array}$ & - \\
\hline Dummy for Asia & - & - & - & - & $\begin{array}{l}-0.060 \\
(0.10)\end{array}$ & - \\
\hline Dummy for South America & - & - & - & - & $\begin{array}{c}-1.196^{*} \\
(2.38)\end{array}$ & - \\
\hline $\begin{array}{l}\text { Average Population } \\
\text { Growth, 1980-1998 }\end{array}$ & - & - & - & - & - & $\begin{array}{l}-0.821 * * \\
(2.82)\end{array}$ \\
\hline Openness (in \% of GDP) & - & - & - & - & - & $\begin{array}{l}0.006 \\
(1.03)\end{array}$ \\
\hline $\begin{array}{l}\text { Government Consumption } \\
\text { (in } \% \text { of GDP) }\end{array}$ & - & - & - & - & - & $\begin{array}{l}-0.011 \\
(0.45)\end{array}$ \\
\hline Inflation & - & - & - & - & - & $\begin{array}{l}-0.020 \\
(1.10)\end{array}$ \\
\hline Constant & -1.352 & -1.646 & -2.136 & -1.920 & -1.004 & -0.038 \\
\hline$\overline{\mathrm{R}}^{2}$ & 0.508 & 0.503 & 0.641 & 0.636 & 0.476 & 0.657 \\
\hline SER & 1.800 & 1.808 & 1.571 & 1.582 & 1.565 & 1.537 \\
\hline J.-B. & 4.206 & 4.975 & 2.327 & 1.719 & 5.226 & 5.191 \\
\hline Observations & 87 & 87 & 73 & 73 & 73 & 73 \\
\hline
\end{tabular}

The numbers in parentheses are the absolute values of the estimated t-statistics, based on the White heteroscedasticity-consistent standard errors. '**', '*' or ' $(*)$ ' show that the estimated parameter is significantly different from zero on the 1,5 , or 10 percent level, respectively. SER is the standard error of the regression, and J. -B. the value of the Jarque-Bera-test on normality of the residuals.

11 We don't report the standard errors without White correction in order not to overburden the tables. They can be obtained from the authors upon request. 


\subsection{Baseline Results}

The estimation results of the baseline specification are presented in Table 1. It is obvious that the three basic economic variables explain average real economic growth per capita quite well (Column (1)). The explanatory variables have the expected signs and high explanatory power. Initial real GDP per capita has a negative impact on economic growth that is significant on the 1 percent significance level. Thus, a catch up-effect can be observed in the cross-country sample used here. The real investment share has the expected positive impact on economic growth and is significant on the 1 percent level, while the secondary school attainment rate has the expected positive impact and is significant on the 5 percent significance level. The dummy variable for transition countries has a significant negative impact on economic growth. This simple growth model explains about 50 percent of the variance of the real growth rate per capita while the hypothesis of normality of the residuals cannot be rejected according to the Jarque-Bera test statistics.

The explanatory power is not improved if the de jure JI indicator is introduced in the model (Column (2)). The adjusted $\mathrm{R}^{2}$ slightly declines from 51 to 50 percent. Adding the de jure $\mathrm{JI}$ indicator to the baseline regression does not affect the estimation results of the baseline regression. De jure JI has the expected positive impact on average real GDP growth per capita but it is not significantly different from zero. Introducing de facto $\mathrm{JI}$ instead of de jure JI (Column (3)) noticeably changes the estimation results however. ${ }^{12}$ It increases the explanatory power of the empirical model measured in the adjusted $\mathrm{R}^{2}$ from 51 to 64 percent. Moreover, and as expected, de facto JI has a positive impact on real economic growth per capita and is significantly different from zero on the 1 percent significance level. The impact of the variables of the baseline regression remains robust, although the significance of the impact of the secondary school attainment rate is reduced to the 10 percent level and the dummy variable for transition countries is not significant anymore. These overall results do not change if both indicators of JI are introduced in one equation (Column (4)). De facto JI has a significantly positive impact on economic growth while the impact of de jure JI changes its sign, but is far from any significance level. The impact of de facto $\mathrm{JI}$ is robust to the inclusion of continental dummies (Column (5)) and additional economic variables (Column (6)), both groups of variables only reduce the significance of the impact of de facto JI to the 5 percent level. While the overall performance of the estimated model is reduced when the continent dummies are included, it increases as compared to the specification reported in Column (4) when the additional economic variables are introduced. In all specifications reported in Table 1, the hypothesis of normal distribution of the residuals cannot be rejected at any conventional significance level. The latter holds for nearly all further estimations and is thus not mentioned anymore. This result is however important to note since it indicates the absence of outliers. 
Table 2: OLS-Regressions of GDP Growth per Capita from 1980 to 1998 on De jure Judicial Independence and Controls, Single Indicators

\begin{tabular}{|c|c|c|c|c|}
\hline Variables & (1) & (2) & (3) & (4) \\
\hline $\begin{array}{l}\text { Highest Court Mentioned in the Constitu- } \\
\text { tion }\end{array}$ & $\begin{array}{l}-1.061 \\
(0.68)\end{array}$ & - & - & - \\
\hline $\begin{array}{l}\text { Competences of Highest Court Enumer- } \\
\text { ated }\end{array}$ & $\begin{array}{l}-3.120 \\
(0.61)\end{array}$ & - & - & - \\
\hline Procedures Specified & $\begin{array}{l}9.169 * \\
(2.22)\end{array}$ & $\begin{array}{l}8.062^{*} \\
(2.08)\end{array}$ & $\begin{array}{l}4.085 \\
(0.92)\end{array}$ & $\begin{array}{l}4.829 \\
(1.30)\end{array}$ \\
\hline Accessibility Specified & $\begin{array}{l}4.694 \\
(1.44)\end{array}$ & $\begin{array}{r}3.940 \\
(1.17)\end{array}$ & $\begin{array}{l}4.986 \\
(1.35)\end{array}$ & $\begin{array}{l}5.152 \\
(1.44)\end{array}$ \\
\hline Term Length Specified & $\begin{array}{l}9.656 \\
(1.02)\end{array}$ & $\begin{array}{l}10.003 \\
(1.37)\end{array}$ & $\begin{array}{l}10.068 \\
(1.36)\end{array}$ & $\begin{array}{l}9.497 \\
(1.32)\end{array}$ \\
\hline Number of Judges Specified & $\begin{array}{l}-0.945 \\
(0.11)\end{array}$ & - & - & - \\
\hline Constitutional Rigidity & $\begin{array}{r}0.479 \\
(0.56)\end{array}$ & - & - & - \\
\hline $\begin{array}{l}\text { Agreement Requirement of Branches of } \\
\text { Government }\end{array}$ & $\begin{array}{l}-0.929 \\
(0.68)\end{array}$ & - & - & - \\
\hline $\begin{array}{l}\text { Majorities at Different Points in Time Re- } \\
\text { quirement }\end{array}$ & $\begin{array}{l}2.509 \\
(0.95)\end{array}$ & - & - & - \\
\hline $\begin{array}{l}\text { Election Methods of the Members of the } \\
\text { Highest Court }\end{array}$ & $\begin{array}{l}0.291 \\
(0.42)\end{array}$ & - & - & - \\
\hline $\begin{array}{l}\text { Ratio of Term of Office and Parliament } \\
\text { Election Period }\end{array}$ & $\begin{array}{l}-2.679 \\
(0.63)\end{array}$ & - & - & - \\
\hline Reelection Possibility of Judges & $\begin{array}{l}0.653 \\
(1.21)\end{array}$ & $\begin{array}{l}0.555 \\
(1.22)\end{array}$ & $\begin{array}{l}0.632 \\
(1.16)\end{array}$ & - \\
\hline Removal of Judges from Office & $\begin{array}{l}-0.099 \\
(0.21)\end{array}$ & - & - & - \\
\hline Accessibility to Highest Court & $\begin{array}{l}-1.145 \\
(1.44)\end{array}$ & $\begin{array}{c}-1.398(*) \\
(1.78)\end{array}$ & $\begin{array}{c}-1.444(*) \\
(1.80)\end{array}$ & $\begin{array}{l}-1.003 \\
(1.46)\end{array}$ \\
\hline Rule for Allocation of Cases & $\begin{array}{l}-0.192 \\
(0.43)\end{array}$ & - & - & - \\
\hline Discretion for Allocation of Cases & $\begin{array}{l}-0.936 \\
(1.53)\end{array}$ & $\begin{array}{l}-0.640 \\
(1.36)\end{array}$ & $\begin{array}{l}-0.281 \\
(0.62)\end{array}$ & - \\
\hline Constitutional Review Part of Constitution & $\begin{array}{l}-0.890 \\
(1.52)\end{array}$ & $\begin{array}{c}-0.986(*) \\
(1.85)\end{array}$ & $\begin{array}{c}-0.910^{*} \\
(2.14)\end{array}$ & $\begin{array}{l}-0.702 \\
(1.48)\end{array}$ \\
\hline Publication Requirements & $\begin{array}{l}0.021 \\
(0.03)\end{array}$ & - & - & - \\
\hline De facto Judicial Independence & - & - & $\begin{array}{l}1.297 * \\
(2.24)\end{array}$ & $\begin{array}{l}1.177 * \\
(2.13)\end{array}$ \\
\hline F-statistics & $1.611(*)$ & $2.803 *$ & $2.709 *$ & $3.025^{*}$ \\
\hline Standard Controls & Robust & Robust & Robust & Robust \\
\hline$\overline{\mathrm{R}}^{2}$ & 0.536 & 0.579 & 0.683 & 0.683 \\
\hline SER & 1.756 & 1.672 & 1.485 & 1.476 \\
\hline J. -B. & 0.129 & 0.474 & 0.567 & 2.546 \\
\hline Observations & 87 & 87 & 73 & 73 \\
\hline
\end{tabular}

For notes see Table 1 . 


\subsection{Results on Single Indicators}

It is easy to recommend the implementation of higher levels of JI in general, but specifying how this can be achieved and what the crucial elements of JI are appears to be more challenging. For questions of constitutional design, the exact specification of the different components of de jure and de facto JI hence promises to be crucial. In order to ascertain the impact of different components of both JI indicators, we include the single indicators separately. Because the answers to the single aspects underlying both indicators are not complete for each question, the missing values are set to the median of each variable. This is a method that can be found quite often in survey studies. Although this might appear to be a questionable method, it does provide insights as to whether there are specific components of JI that exert particular impacts on economic growth. With respect to de jure JI, the respective results as reported in Table 2, Column (1) support those from the baseline specifications. Since some variables are positively and others negatively correlated with GDP growth, it is no surprise that the index as an aggregate of those countervailing influences does not have any significant impact. Moreover, nearly none of the single indicators exhibits a statistically significant individual impact on GDP growth. There is, however, one exception: The anchoring of the specification of procedures of the highest courts in the constitution is significant on the 5 percent level and exhibits a positive sign. In addition, several variables show t-statistics that are higher than 1 such that the hypothesis that all indicators of de jure JI together have no impact of real GDP growth per capita can be rejected on the 10 percent level $($ F-statistic $=1.611)$.

In a next step, we thus drop individual variables by testing on their redundancy and keep those variables for which redundancy is rejected. The final results of this procedure are reported in Column (2). Seven single components of de jure JI appear to have a common impact on economic growth. At least, the hypothesis that they have no impact is rejected on the 5 percent significance level $(\mathrm{F}=2.803)$. Again, the anchoring of the specification of procedures of the highest courts in the constitution exhibits a positive sign, which is significant on the 5 percent level. In addition, the broad accessibility of courts and the court's power for constitutional review are both significant at the 10 percent level and have a negative impact on economic growth. The drawback of the estimation results in Column (2) of Table 2 on single components of de jure $\mathrm{JI}$ is that the impact of de facto $\mathrm{JI}$ is not controlled for. Including the index of de facto JI (Column (3)) affects the results notably. We thus test again on redundancy of different groups of variables and exclude those, for which redundancy cannot be rejected, a procedure that finally leaves us with the estimated equation in Column (4). The hypothesis that reelection possibilities of judges and discretion in the allocation of cases do not have a joint impact on real GDP growth per capita cannot be rejected on any conventional significance level $(\mathrm{F}=0.816)$. The anchoring of a specification of procedures, of the accessibility of the highest courts as well as the term length of its judges in the constitution as well as the broad accessibility to the highest court and the power for constitutional review do, however, 
have a joint impact on economic growth $(\mathrm{F}=3.025)$. According to these results, mainly the specification of the powers and procedures of the court have a (modest in statistical terms) positive impact on economic growth. If they are specified in the constitution itself, there is a greater degree of independence than if they are simply fixed by ordinary law. However, the broad accessibility to highest courts and the power for constitutional review exert a negative impact on economic growth. Neither the appointment procedure, nor judicial tenure, the legal term length or publication requirements appear to play an additional role.

Table 3: OLS-Regressions of GDP Growth per Capita from 1980 to 1998 on De Facto Judicial Independence and Controls, Single Indicators

\begin{tabular}{|c|c|c|c|c|c|}
\hline Variables & (1) & (2) & (3) & (4) & (5) \\
\hline $\begin{array}{l}\text { Measures against Income Reductions } \\
\text { of Judges }\end{array}$ & $\begin{array}{l}0.207 \\
(0.49)\end{array}$ & - & - & - & - \\
\hline $\begin{array}{l}\text { Adequate Payment of Judges Legally } \\
\text { Fixed }\end{array}$ & $\begin{array}{l}-0.165 \\
(0.22)\end{array}$ & - & - & - & - \\
\hline $\begin{array}{l}\text { Effective Average Term Length of } \\
\text { Judges }\end{array}$ & $\begin{array}{r}0.351 \\
(0.35)\end{array}$ & $\begin{array}{r}0.389 \\
(0.41)\end{array}$ & - & - & - \\
\hline $\begin{array}{l}\text { No or Small Deviations from 'Normal' } \\
\text { Average Term Length }\end{array}$ & $\begin{array}{c}1.033(*) \\
(1.71)\end{array}$ & $\begin{array}{l}1.180^{*} \\
(2.23)\end{array}$ & $\begin{array}{l}1.205^{*} \\
(2.33)\end{array}$ & $\begin{array}{l}1.178^{*} \\
(2.24)\end{array}$ & $\begin{array}{l}1.148^{*} \\
(2.10)\end{array}$ \\
\hline $\begin{array}{l}\text { Small Numbers of Effective Removals } \\
\text { before End of Term }\end{array}$ & $\begin{array}{l}0.505 \\
(1.05)\end{array}$ & $\begin{array}{r}0.570 \\
(1.22)\end{array}$ & $\begin{array}{r}0.577 \\
(1.24)\end{array}$ & $\begin{array}{l}0.584 \\
(1.26)\end{array}$ & - \\
\hline $\begin{array}{l}\text { No or Small Changes of the Number of } \\
\text { Judges }\end{array}$ & $\begin{array}{l}1.378^{*} \\
(2.02)\end{array}$ & $\begin{array}{l}1.437^{*} \\
(2.14)\end{array}$ & $\begin{array}{l}1.428^{*} \\
(2.14)\end{array}$ & $\begin{array}{l}1.414^{*} \\
(2.13)\end{array}$ & $\begin{array}{l}1.483 * \\
(2.06)\end{array}$ \\
\hline Real Income At Least Constant & $\begin{array}{c}1.508 * * \\
(2.78)\end{array}$ & $\begin{array}{l}1.458 * * \\
(3.14)\end{array}$ & $\begin{array}{l}1.467 * * \\
(3.12)\end{array}$ & $\begin{array}{l}1.052^{*} \\
(2.57)\end{array}$ & $\begin{array}{l}1.045^{*} \\
(2.54)\end{array}$ \\
\hline $\begin{array}{l}\text { Budget of the Highest Court At Least } \\
\text { Constant }\end{array}$ & $\begin{array}{l}-0.629 \\
(1.11)\end{array}$ & $\begin{array}{l}-0.548 \\
(1.18)\end{array}$ & $\begin{array}{l}-0.550 \\
(1.18)\end{array}$ & - & - \\
\hline $\begin{array}{l}\text { No or Small Number of Changes of } \\
\text { Relevant Articles of the Constitution }\end{array}$ & $\begin{array}{r}0.672 \\
(0.70)\end{array}$ & - & - & - & - \\
\hline $\begin{array}{l}\text { No or Small Implementation Deficit of } \\
\text { Court's Rulings }\end{array}$ & $\begin{array}{c}0.485 \\
(0.73)\end{array}$ & - & - & - & - \\
\hline F-statistics & $3.112 * *$ & $4.287 * *$ & $5.056 * *$ & $4.390 * *$ & $5.280 * *$ \\
\hline Standard Controls & Robust & Robust & Robust & Robust & Robust \\
\hline$\overline{\mathrm{R}}^{2}$ & 0.561 & 0.575 & 0.580 & 0.582 & 0.580 \\
\hline SER & 1.700 & 1.672 & 1.662 & 1.658 & 1.663 \\
\hline J. -B. & 0.909 & 1.965 & 1.845 & 1.426 & 1.499 \\
\hline Observations & 73 & 73 & 73 & 73 & 73 \\
\hline
\end{tabular}

For notes see Table 1. The estimation results for the Dummy for Transition Countries are not reported.

Following the same procedure of exclusion of variables, we obtain the main components of $d e$ facto JI that have an impact on economic growth. ${ }^{13}$ According to the results in Column (5) of

13 Comparing the estimated equation in Column (1) with that in Column (5) of Table 3, the hypothesis that the excluded variables are redundant cannot be rejected on any significance level $($ F-statistic $=0.522)$. 
Table 3, the positive impact of de facto JI on economic growth is mainly obtained for countries with no or only slight deviations from the 'normal' average term length of judges, those with a small number of changes of the number of judges and those countries that secure at least a real constancy of judges' salaries. These three variables each have a positive impact on economic growth that is significant on the 5 percent level. Excluding one of these variables in turn leaves the impact of the remaining two variables unaffected.

\subsection{Interaction of Judicial Independence with Organizational, Constitutional, Legal and Political Environment}

As outlined above, judicial independence might work differently in different environments. The organizational environment of the highest courts is described by three variables in this paper. First, the legal origin of a country as a kind of legal tradition is included as an explanatory variable. La Porta et al. (1999) distinguish between English, Socialist, French, Scandinavian and German legal origin. ${ }^{14}$ Column (1) in Table $4 a$ contains the estimation results of the baseline specification including the two JI indicators and the legal origin dummies of which we chose to exclude the Scandinavian legal origin dummy in place of the constant term. The inclusion of the legal origin variables does not have an impact on the estimation results of the two JI variables. As before, de facto JI is significant at the 1 percent level and has a positive impact on economic growth, while de jure JI does not reach any significance level. Of the legal origin variables, only socialist legal origin has a significant positive impact although the hypothesis that the legal origin variables has no impact on economic growth is rejected on the 1 percent significance level $(\mathrm{F}=17.811){ }^{15}$

14 Please note that the dummy variable for socialist legal origin and that for transition countries are not identical because the latter comprises the former USSR countries and the Eastern European countries only, but not China, Vietnam, Cambodia, and some African former socialist countries.

15 That socialist legal origin has a significant positive impact should not worry because East European transition countries are controlled for by the dummy for Eastern European countries such that the Socialist legal origin dummy mainly controls for China, Vietnam, Cambodia, and some African former socialist countries. 
Table 4a: Regressions of GDP Growth per Capita from 1980 to 1998 on Judicial Independence and Controls, Interactions with Legal and Constitutional Environment

\begin{tabular}{|c|c|c|c|c|c|}
\hline Variables & (1) & (2) & (3) & (4) & (5) \\
\hline $\begin{array}{l}\text { De jure Judicial Independ- } \\
\text { ence }\end{array}$ & $\begin{array}{l}-0.032 \\
(0.02)\end{array}$ & $\begin{array}{l}-0.476 \\
(0.29)\end{array}$ & $\begin{array}{l}-0.852 \\
(0.53)\end{array}$ & $\begin{array}{l}-0.357 \\
(0.22)\end{array}$ & $\begin{array}{l}-0.373 \\
(0.23)\end{array}$ \\
\hline $\begin{array}{l}\text { Defacto Judicial Independ- } \\
\text { ence }\end{array}$ & $\begin{array}{c}1.970 * * \\
(2.98)\end{array}$ & $\begin{array}{l}1.959 * * \\
(3.20)\end{array}$ & $\begin{array}{l}2.922 * * \\
(3.41)\end{array}$ & $\begin{array}{l}2.041^{* *} \\
(3.12)\end{array}$ & $\begin{array}{c}1.969 * * \\
(2.71)\end{array}$ \\
\hline \multicolumn{6}{|l|}{ Additional Variables } \\
\hline English Legal Origin & $\begin{array}{l}0.017 \\
(0.03)\end{array}$ & - & - & - & - \\
\hline Socialist Legal Origin & $\begin{array}{c}3.140 * * \\
(4.52)\end{array}$ & - & - & - & - \\
\hline French Legal Origin & $\begin{array}{l}-0.589 \\
(1.21)\end{array}$ & - & - & - & - \\
\hline German Legal Origin & $\begin{array}{l}-0.528 \\
(0.78)\end{array}$ & - & - & - & - \\
\hline F-statistic: Legal Origin & $17.811 * *$ & - & - & - & - \\
\hline Age of the Constitution & - & $\begin{array}{l}0.004^{*} \\
(2.12)\end{array}$ & $\begin{array}{l}0.019 * * \\
(3.11)\end{array}$ & - & - \\
\hline $\begin{array}{l}\text { Age of the Constitution * } \\
\text { De facto Judicial Independ- } \\
\text { ence }\end{array}$ & - & - & $\begin{array}{l}-0.022^{*} \\
(2.59)\end{array}$ & - & - \\
\hline Constitutional Court & - & - & - & $\begin{array}{l}-0.537 \\
(1.22)\end{array}$ & $\begin{array}{l}-0.624 \\
(0.70)\end{array}$ \\
\hline $\begin{array}{l}\text { Constitutional Court * De } \\
\text { facto Judicial Independence }\end{array}$ & - & - & - & - & $\begin{array}{l}0.150 \\
(0.13)\end{array}$ \\
\hline $\begin{array}{l}\text { Dummy for Transition } \\
\text { Countries }\end{array}$ & $\begin{array}{l}-4.356^{* *} \\
(4.50)\end{array}$ & $\begin{array}{l}-0.775 \\
(0.87)\end{array}$ & $\begin{array}{l}-0.637 \\
(0.74)\end{array}$ & $\begin{array}{l}-0.722 \\
(0.77)\end{array}$ & $\begin{array}{l}-0.700 \\
(0.74)\end{array}$ \\
\hline Standard Controls & Robust & Robust & Robust & Robust & Robust \\
\hline $\begin{array}{l}\text { F-statistics: De Facto Judi- } \\
\text { cial Independence }\end{array}$ & - & - & $5.838 * *$ & - & $6.498 * *$ \\
\hline $\begin{array}{l}\text { F-statistics: Age of the } \\
\text { Constitution }\end{array}$ & - & - & $4.830 * *$ & - & - \\
\hline $\begin{array}{l}\text { F-statistics: Constitutional } \\
\text { Court }\end{array}$ & - & - & - & - & 0.835 \\
\hline$\overline{\mathrm{R}}^{2}$ & 0.648 & 0.649 & 0.664 & 0.639 & 0.634 \\
\hline SER & 1.554 & 1.572 & 1.540 & 1.574 & 1.586 \\
\hline J.-B. & $4.758(*)$ & 1.876 & 0.763 & 1.130 & 0.963 \\
\hline Observations & 73 & 71 & 71 & 73 & 73 \\
\hline
\end{tabular}

For notes see Table 1. Results for the standard controls and constant are not reported. 
Table 4b: Regressions of GDP Growth per Capita from 1980 to 1998 on Judicial Independence and Controls, Interactions with Legal and Constitutional Environment

\begin{tabular}{|c|c|c|c|c|c|c|}
\hline Variables & (1) & (2) & (3) & (4) & (5) & (6) \\
\hline $\begin{array}{l}\text { De jure Judicial Independ- } \\
\text { ence }\end{array}$ & $\begin{array}{l}-0.418 \\
(0.26)\end{array}$ & $\begin{array}{l}-0.379 \\
(0.23)\end{array}$ & $\begin{array}{l}-0.116 \\
(0.08)\end{array}$ & $\begin{array}{l}-0.632 \\
(0.43)\end{array}$ & $\begin{array}{l}-0.991 \\
(0.58)\end{array}$ & $\begin{array}{l}-0.954 \\
(0.54)\end{array}$ \\
\hline $\begin{array}{l}\text { De facto Judicial Independ- } \\
\text { ence }\end{array}$ & $\begin{array}{l}1.904 * * \\
(3.17)\end{array}$ & $\begin{array}{r}0.909 \\
(1.06)\end{array}$ & $\begin{array}{c}1.580 * * \\
(3.04)\end{array}$ & $\begin{array}{c}2.581 * * \\
(2.84)\end{array}$ & $\begin{array}{c}2.117 * * \\
(3.16)\end{array}$ & $\begin{array}{c}1.817 * * \\
(2.68)\end{array}$ \\
\hline \multicolumn{7}{|l|}{ Additional Variables } \\
\hline Checks and Balances & $\begin{array}{l}0.119 * \\
(2.07)\end{array}$ & $\begin{array}{l}-0.120 \\
(0.61)\end{array}$ & - & - & - & - \\
\hline $\begin{array}{l}\text { Checks and Balances * De } \\
\text { facto Judicial Independence }\end{array}$ & - & $\begin{array}{l}0.298 \\
(1.49)\end{array}$ & - & - & - & - \\
\hline Parliamentary System & - & - & $\begin{array}{c}0.729 * * \\
(3.26)\end{array}$ & $\begin{array}{c}1.190 * * \\
(3.46)\end{array}$ & - & - \\
\hline $\begin{array}{l}\text { Parliamentary System } * D e \\
\text { facto Judicial Independence }\end{array}$ & - & - & - & $\begin{array}{c}-0.996(*) \\
(1.75)\end{array}$ & - & - \\
\hline Federalism & - & - & - & - & $\begin{array}{l}-0.235 \\
(0.51)\end{array}$ & $\begin{array}{l}-0.995 \\
(1.02)\end{array}$ \\
\hline $\begin{array}{l}\text { Federalism * De facto Judi- } \\
\text { cial Independence }\end{array}$ & - & - & - & - & - & $\begin{array}{l}1.330 \\
(1.04)\end{array}$ \\
\hline $\begin{array}{l}\text { Dummy for Transition } \\
\text { Countries }\end{array}$ & $\begin{array}{c}-1.091 \\
(1.25)\end{array}$ & $\begin{array}{l}-1.013 \\
(1.15)\end{array}$ & $\begin{array}{l}-1.374 \\
(1.60)\end{array}$ & $\begin{array}{c}-1.441\left(^{*}\right) \\
(1.72)\end{array}$ & $\begin{array}{l}-1.641 \\
(1.48)\end{array}$ & $\begin{array}{l}-1.567 \\
(1.46)\end{array}$ \\
\hline Standard Controls & Robust & Robust & Robust & Robust & Robust & Robust \\
\hline $\begin{array}{l}\text { F-statistics: De Facto Judi- } \\
\text { cial Independence }\end{array}$ & - & $5.688 * *$ & - & $4.806^{*}$ & - & $5.595 * *$ \\
\hline $\begin{array}{l}\text { F-statistics: Checks and } \\
\text { Balances }\end{array}$ & - & $6.718 * *$ & - & - & - & - \\
\hline $\begin{array}{l}\text { F-statistics: Parliamentary } \\
\text { System }\end{array}$ & - & - & - & $6.881 * *$ & - & - \\
\hline F-statistics: Federalism & - & - & - & - & - & 0.559 \\
\hline$\overline{\mathrm{R}}^{2}$ & 0.468 & 0.467 & 0.678 & 0.688 & 0.459 & 0.459 \\
\hline SER & 1.577 & 1.578 & 1.488 & 1.463 & 1.625 & 1.625 \\
\hline J.-B. & 2.758 & 2.261 & 1.903 & 1.285 & 0.177 & 0.028 \\
\hline Observations & 73 & 73 & 73 & 73 & 63 & 63 \\
\hline
\end{tabular}

For notes see Table 1. Results for the standard controls and constant are not reported.

Second, the organizational environment is captured by the age of the constitution. ${ }^{16}$ It could be argued that de facto $\mathrm{JI}$ is higher in countries that have not had many changes in their constitutions for the last 40 years. This argument stems from the construction of the de facto index that includes information on changes in the number of judges since 1960, real constancy of income and budget of judges since 1960 and so on. If the argument holds, newly created

16 Including that variable reduces the number of observations by 2 because it is difficult to assess the age of a constitution in countries that do not possess a formal constitutional document like, e.g. England. 
countries with new constitutions would have a clear disadvantage by construction. Column (2) of Table $4 a$ presents the results of the JI augmented baseline model to which the age of the constitution is included. The higher the age of the constitution, the higher is economic growth of the respective country - ceteris paribus. The impact of the age of the constitution is significant on the 5 percent significance level. The JI augmented baseline model is however not affected by the inclusion of that variable. In particular, the significant positive impact of de facto JI remains robust. Interacting de facto JI with the age of the constitution reveals an interesting result. While the basic impacts of de facto JI and the age of the constitution remain robust and keep their significant positive impacts on economic growth, the interaction term is significantly negative. Countries with old constitutions experience significantly lower real GDP growth per capita given that they have a high degree of de facto JI. Turning this result around, it can be inferred that countries with new constitutions will experience higher growth rates given that they have a high degree of de facto JI. Unfortunately, the partial correlation coefficient between the variable "age of constitution" and de facto $\mathrm{JI}$ is -.31 , implying that the probability that a country with a young constitution manages to have a high degree of de facto $\mathrm{JI}$ is rather low. The results are different if real per capita GDP is used as the dependent variable. De facto judicial independence has a positive impact on real GDP per capita with an estimated coefficient of 3561.23 that is significant at the 5 percent level (t-statistics 2.20), while the age of the constitution also exerts a positive influence of 58.75 that is significant at the 1 percent level (t-statistics 5.18). An analysis of the interaction between both variables reveals an insignificant positive effect for the interaction term, while the significance of $d e$ facto $\mathrm{JI}$ is reduced to the 10 percent level $(\mathrm{F}=2.788) .{ }^{17}$ Hence, the effect of age of the constitution on economic performance is independent of judicial independence.

Third and most importantly, the consequences of JI may depend on the underlying court model. As argued above, constitutional review can be allocated to each court of a country as in the U.S., to a specialized constitutional court that deals with constitutional matters as in Germany or to a special body that is constrained to ex ante review as in France. With respect to the relevance of JI, the Constitutional Court model might have an advantage over the other two because it entails the power for ex ante and ex post as well as abstract and concrete review. Hence, a dummy variable being one for a constitutional court according to the Austrian model and zero otherwise is included in the estimated equation. As reported in Columns (3) and (4), neither the constitutional court variable nor its interaction term with de facto JI has

17 The detailed results can be obtained from the authors upon request. Extending the analysis to real per capita GDP instead of growth is beyond the scope of this paper. It would also be preferable to analyze the impact of judicial independence on total factor productivity. This will be one of our next projects. 
any significant impact on economic growth, while the impact of de facto JI remains robust and keeps the significant positive impact. ${ }^{18}$

In addition to the organizational environment, other constitutional provisions might shape the impact of JI on economic growth. We focus on three different variables again. First, the extent of checks and balances is included in the model by drawing on an ordinally scaled variable provided by Beck et al. (2000). The higher the extent of checks and balances in a constitution, the higher are the values of that variable. According to the results in Column (1) of Table 4b, the more checks and balances a constitution contains, the higher is economic growth. This variable is significant at the 5 percent significance level, but leaves the significant positive impact of de facto JI unaffected. The interaction of de facto JI with the checks and balances variable does not entail clear-cut results. The overall effect of both de facto variables remains significant $(F=5.688)$, like the overall effect of checks and balances remains significantly different from zero $(\mathrm{F}=6.718)$. The interaction term is not significant however. If anything, the existence of strong checks and balances enforces the impact of de facto JI on economic growth.

Closely connected to the checks and balances discussion is the political economics analysis of presidential versus parliamentary systems. In order to control for the differences in these systems, a variable provided by Beck et al. (2000) is used that adopts values of zero for direct elections of the president, 1 for a strong president elected by an assembly and 2 for elections of the head of state by the parliament. The results in Columns (3) and (4) of Table $4 b$ indicate that parliamentary systems have significantly higher growth rates between 1980 and 1998 than presidential systems. These results corroborate the findings by Persson and Tabellini (2003, Chap. 7) who find that presidential systems have a lower labor productivity. While the significantly positive impact of de facto JI remains robust in both equations, it is most interesting that the interaction term of de facto JI and the parliamentary system variable has a significant negative impact indicating that the growth enhancing effect of de facto JI in particular exists in presidential systems. ${ }^{19}$ Finally, including a dummy variable for federalism as an ind icator for the extent of vertical checks and balances does not have any significant impact on economic growth as Columns (5) and (6) in Table $4 b$ reveal.

18 We estimated the same equation by re-coding the constitutional court variable such that the French model was not taken together with the American model. In this case, the absence of a constitutional court is measured while the variable in Table 4 a captures the presence of a constitutional court. The results remained virtually the same. Perhaps an even more differentiated analysis must be left to our future research.

19 Caution in the interpretation of this result is, of course, warranted. From earlier research (Hayo and Voigt 2003), we know that parliamentary systems are significantly more likely than presidential systems to realize high degrees of de facto JI. It is thus possible to suspect that the few presidential systems that were able to realize high degrees of de facto JI have been growing at faster rates than the large number of presidential systems that were not able to realize high levels of de facto JI. 
Table 4c: Regressions of GDP Growth per Capita from 1980 to 1998 on Judicial Independence and Controls, Interactions with Legal and Constitutional Environment

\begin{tabular}{|c|c|c|c|c|}
\hline Variables & (1) & (2) & (3) & (4) \\
\hline De jure Judicial Independence & $\begin{array}{l}-0.443 \\
(0.27)\end{array}$ & $\begin{array}{l}-0.580 \\
(0.34)\end{array}$ & $\begin{array}{l}-0.127 \\
(0.09)\end{array}$ & $\begin{array}{l}-0.627 \\
(0.41)\end{array}$ \\
\hline De facto Judicial Independence & $\begin{array}{c}1.870 * * \\
(3.31)\end{array}$ & $\begin{array}{l}1.108 \\
(0.80)\end{array}$ & $\begin{array}{l}1.669^{*} \\
(2.63)\end{array}$ & $\begin{array}{c}2.999 * * \\
(2.91)\end{array}$ \\
\hline \multicolumn{5}{|l|}{ Additional Variables } \\
\hline Age of the Constitution & - & - & $\begin{array}{l}0.010^{*} \\
(2.39)\end{array}$ & $\begin{array}{c}0.015(*) \\
(1.94)\end{array}$ \\
\hline $\begin{array}{l}\text { Age of the Constitution * De facto } \\
\text { Judicial Independence }\end{array}$ & - & - & - & $\begin{array}{l}-0.013 \\
(1.22)\end{array}$ \\
\hline Constitutional Court & - & - & $\begin{array}{l}-0.201 \\
(0.38)\end{array}$ & $\begin{array}{l}-0.231 \\
(0.45)\end{array}$ \\
\hline Parliamentary System & - & - & $\begin{array}{c}0.936^{* *} \\
(3.71)\end{array}$ & $\begin{array}{c}1.114^{* *} \\
(3.11)\end{array}$ \\
\hline $\begin{array}{l}\text { Parliamentary System * De facto } \\
\text { Judicial Independence }\end{array}$ & - & - & - & $\begin{array}{l}-0.563 \\
(0.94)\end{array}$ \\
\hline Checks and Balances & - & - & $\begin{array}{l}0.018 \\
(0.21)\end{array}$ & $\begin{array}{l}0.018 \\
(0.20)\end{array}$ \\
\hline Federalism & - & - & $\begin{array}{l}-0.453 \\
(0.98)\end{array}$ & $\begin{array}{l}-0.297 \\
(0.65)\end{array}$ \\
\hline Free Press & $\begin{array}{l}-0.003 \\
(0.16)\end{array}$ & $\begin{array}{l}-0.010 \\
(0.44)\end{array}$ & $\begin{array}{l}-0.005 \\
(0.31)\end{array}$ & $\begin{array}{l}-0.002 \\
(0.14)\end{array}$ \\
\hline $\begin{array}{l}\text { Free Press * De facto Judicial } \\
\text { Independence }\end{array}$ & - & $\begin{array}{l}0.022 \\
(0.60)\end{array}$ & - & - \\
\hline Dummy for Transition Countries & $\begin{array}{l}-1.073 \\
(1.21)\end{array}$ & $\begin{array}{l}-1.139 \\
(1.23)\end{array}$ & $\begin{array}{c}-1.753(*) \\
(1.70)\end{array}$ & $\begin{array}{l}-1.575 \\
(1.54)\end{array}$ \\
\hline Standard Controls & Robust & Robust & Robust & Robust \\
\hline $\begin{array}{l}\text { F-statistics: De Facto Judicial } \\
\text { Independence }\end{array}$ & - & $5.623 * *$ & - & $3.047^{*}$ \\
\hline F-statistics: Free Press & - & 0.178 & - & - \\
\hline $\begin{array}{l}\text { F-statistics: Age of the Constitu- } \\
\text { tion }\end{array}$ & - & - & - & 2.321 \\
\hline F-statistics: Parliamentary System & - & - & - & $6.215^{* * *}$ \\
\hline$\overline{\mathrm{R}}^{2}$ & 0.630 & 0.628 & 0.572 & 0.578 \\
\hline SER & 1.594 & 1.599 & 1.468 & 1.457 \\
\hline J.-B. & 1.529 & 1.300 & 1.389 & 1.521 \\
\hline Observations & 73 & 73 & 61 & 61 \\
\hline
\end{tabular}

For notes see Table 1. Results for the standard controls and constant are not reported.

With respect to the political environment of JI, only the results of the free press are shown in the first two columns of Table $4 c$. Neither the free press, nor the interaction term has any significant impact on economic growth while de facto JI remains robust. In addition, we analyzed the impact of ethnic fractionalization and political stability in this model of economic 
growth. Since the results are pretty much in line with those reported by Feld and Voigt (2003), we abstain from reporting them here. Finally, all different organizational, constitutional and political variables are included in the model jointly with the two JI indicators. The results are reported in Columns (3) and (4) of Table 4c. As before, de facto JI keeps its $1 \mathrm{e}$ markably robust impact on economic growth while the age of the constitution and the parliamentary system variable keep their impact from the above analysis under ceteris paribus conditions. The single interaction terms are not significant any more. We chose to show only those for the two variables mentioned before. The two de facto JI variables $(\mathrm{F}=3.047)$ and the two parliamentary system variables $(F=6.215)$ are jointly significant, while the two age of constitution variables $(F=2.321)$ are not. Still these two reported interaction terms keep their signs from the analysis before such that some modest support for these hypotheses emains.

\section{$5 \quad$ Consequences for Constitutional Design}

Until now, we have solely reported the statistical significance of JI on economic growth. For issues of constitutional design, this is, of course, insufficient. Advising constitutional designers to put great emphasis on creating the prerequisites for an independent judiciary will only be justified if its effects are also economically significant. This is indeed the case: a switch from a totally dependent to a totally independent judiciary would - ceteris paribus - lead to an increase in growth rates of between 1.5 to 2.1 percentage points according to our estimates. ${ }^{20}$ This is an enormous increase in economic growth which implies that real per capita GDP of a country with such an extreme constitutional switch would double in 33 to 47 years.

Taken at face value, the consequences of our analysis for constitutional design are quite obvious: With respect to de jure JI, (i) the specification of the court procedures in the constitution, (ii) the accessibility of the highest court, and (iii) the term length of its judges have a (modest in statistical terms) positive impact on economic growth. It would thus seem that special emphasis should be given to these three issues. However, establishing a broad access to the highest courts by individuals as well as enabling the court by constitutional means for constitutional review do not appear to be conducive to economic growth. At first sight this might contradict the separation of powers view. Both characteristics of independent courts extend their veto power such that political stalemate might result. This is clearly counter-productive in economic terms. Neither the appointment procedure, nor judicial tenure, the legal term

The switch in judicial independence in that example is the range of the de facto JI variable. The growth rates mentioned in that example are derived from the minimum and maximum estimates in our regressions without interaction terms. - According to comparative institutional analysis, the net present value of additional growth would have to be compared with the costs of establishing a (more) independent judiciary. Only if the former figure is larger than the latter a sufficient reason for trying to implement a (more) independent judiciary exists. 
length or publication requirements appear to play an additional role. It should be noted that it is the specification in the constitution that matters instead of the relative term length of judges for example vis-à-vis the other branches of government, as conjectured by Padovano, Sgarra, and Fiorino (2003). The key to understand this result lies in the fact that constitutional revision is more costly such that judges are more strongly insured against discretion of other branches of government. These results lend support to the hypothesis that the entrenchment of $\mathrm{JI}$ in the constitution is important compared to its foundation in simple legislation. In turn, this leads to the advice to fix procedures and powers of the judiciary in the constitution.

With respect to de facto JI, our results indicate that no or only slight deviations from the 'normal' average term length of judges, a small number of changes of the number of judges and keeping judges' salaries at least constant in real terms make up for the overall strong impact of de facto JI on economic growth. The first two components are a result of the constraints that the other branches of government have displayed vis-à-vis the judiciary. The last component supports the notion that judicial independence is also a function of monetary rewards. If the members of one of the other government branches determine judges' salaries, this raises incentives to take the preferences of these members explicitly into account. These results lead to two suggestions: (1) Reduce the actual use of discretionary power of the other branches of government vis-à-vis the judiciary; (2) pay judges adequately.

That an old and stable constitution is not necessarily a precondition for de facto JI to exert its positive impact on economic growth is good news for countries willing to pass a new constitution with increased JI. Moreover, the positive impact of de facto JI is independent of the legal origin of a country and the court type. One size does thus not necessarily have to fit all. Other considerations in the choice of the court structure can come in without having to make cuts in the aim of setting up the judiciary in a way that is maximizing the probability to experience economic growth. De facto JI interacts, however, with the basic constitutional provisions. According to our results, JI positively influences economic growth particularly in presidential systems. It appears to be a necessary component of the checks and balances or the separation of powers in presidential systems. This leads to the advice to introduce high extents of de facto JI in order to restrict the powers of a strong president.

But a word of caution concerning these recommendations is in order: we have focused on one important part of the constitution - the judiciary - and possibilities to make it effective. Yet, the introduction of judicial independence in an environment otherwise completely hostile to economic development might not have many beneficial effects: what happens if you formally introduce judicial independence, but the legal rules that the judiciary is to decide upon are inadequate for development? What happens if a newly established regime keeps the old corrupt judges and endows them with independence? This shows that judicial independence can only be one part of a larger picture; as such it is not sufficient to induce additional growth. 
A recent issue of the World Development Report (2002,chp. 6) has dealt with one part of the problem, namely judicial efficiency and proposes (i) increased accountability of judges, (ii) simplification, and (iii) increased resources. Increased accountability is supposed to be dbtained by information on judicial performance, judges who work on individual calendar, a reporting of judicial statistics. Moreover, open trials would enable everybody to observe judges' conduct and keep them accountable. While we have not explicitly dealt with judicial accountability in this paper, Hayek's $(1960,192)$ suggestion to supplement judicial independence by instruments of direct democracy in order to make judges accountable is well worth noting again. Curiously enough, it is often representatives of the legal science like lawyers, law professors and judges who oppose the introduction of direct democracy.

The paper has not dealt with the political economy of JI. From the empirical support for the hypothesis that JI is conducive to economic growth we have inferred that it should be designed on the constitutional stage. Yet, an independent judiciary can make the lives of go vernment members more complicated because it acts as an additional constraint upon their behavior. If members of the legislature and the executive are crucial for constitutional design, considerations as these will often prevent them from installing an independent judiciary.

Finally, de facto judicial independence is what matters most. Despite the fact that the age of the constitution does not appear to be a precondition of de facto JI, it is not sufficient to write JI in new legal or constitutional documents without acquiring some reputation that the state lives up to JI de facto. Reputation building still is a time consuming and costly exercise and moreover its dynamics are asymmetric in the sense that it is difficult to build up but easily and quickly destroyed. Both the political economy aspect and the importance of factual JI indicate the potential for time inconsistency in actually creating an independent judiciary.

\section{Conclusions and Out look}

In this paper, we have investigated the impact of judicial independence (JI) on economic growth for a cross section of about 80 countries. By extending the analysis of Feld and Voigt (2003), we use two indicators of JI introduced by them, one measuring de jure and another measuring de facto JI. Basically, the results of Feld and Voigt are reproduced for a larger sample, although they are stronger and more robust: De facto JI has a strong, significantly positive impact on economic growth, while de jure JI does not. Differentiating the impact of single components of both indicators and looking at their interaction with the organizational and constitutional environment, some suggestions for constitutional design are obtained. First, it appears to be useful to specify procedures and powers of the judiciary in the constitution instead of granting independence only legally. Second, reduce the actual use of discretionary power of the other branches of government vis-à-vis the judiciary and pay judges adequately. 
Third, introduce high extents of de facto JI in particular in presidential systems in order to restrict the powers of a strong president.

The most important issue for future research seems to be to improve our knowledge concerning the channels through which JI has an impact on economic growth. One way to approach this issue is to estimate the amount of additional (foreign direct) investment that is triggered by having a more independent judiciary on the one hand and to estimate the growth in productivity of capital already in use that can be attributed to an independent judiciary. Another way to approach this issue is to go back to our story that there are three paradigmatic interaction situations that could be influenced by the existence of an independent judiciary, namely interactions between private citizens, interactions between citizens and the state, and interactions between government branches. The first interaction situation is within the realm of private law, whereas the other two situations are within the realm of public law. Knowing more about the channels through which JI has an impact on economic growth would, of course, enable us to give constitutional advice on a more solid basis.

Acknowledgment: The following persons helped tremendously with this project either by completing the questionnaire themselves or by re-sending it to country experts: Angela Baronin Adamovich (Croatia); Christian Alsøe (Denmark); Carlos Amayo O. (Colombia); Beth Aub (Jamaica); Thompson Ayodele (Nigeria); Adrian Baboi - Stroe (Romania); Maja Bacovic (Montenegro); Roberto Dala Barba Filho (Brasil); Abdel Azuz Bari (Malaysia); Andrea Behn (Cambodia); Maria Isabel Bonilla (Guatemala); Gyimah Boadi (Ghana); Boudewijn Bouckaert (Belgium); Nathan Brown (Egypt and Kuwait); Birgit Calix (Honduras); Katja Chammas (Lebanon); Fréderique Chancellier (France); Alfred W. Chanda (Zambia); Giovanni Cordini (Italy); Bibek Debroy (India); Jacques Dinan (Mauritius); Alaa Elemary (Egypt); Vladan Djuranovic (Montenegro); Fredrik Erixon (Sweden); Aissata Fall Bagnan (Niger); Charles Fornbad (Botswana); Marie-Noëlle Ferrieux Patterson (Vanuatu); Diogo de Figueiredo Moreira Neto (Brazil); R. Fischer (Chile); Ricardo Flores (Venezuela); Tamás Földi (Hungary); Pedro Galilea (Spain); Enrique Ghersi (Peru); Thomas Ginsburg (USA); Docent Jaan Ginter (Estonia); John Githongo (Kenya); Dr. Arturo R. Oliver González (Mexico); Jorge Hernandez (Peru); Benedikte Holberg (Dänemark); Stephan Hulka (Czech Republic); Robert Jagtenberg (Netherlands); Ikbal Janif (Fiji); Jae Ho Chung (South Korea); Akritas Kaidatzis (Greece); Hein Kiessling (Pakistan); Gia Kiknadze (Georgia); Sa'eda Kilani (Jordan); Victor Kimesera (Tanzania); Wolfgang Kleine (Namibia); Amalia Kostanyan (Armenia); Peter Kurrild-Klitgaard (Denmark); Andreas Kyriacou (Cyprus); Toh Han Li (Singapore); Elena A. Lisovskaya (Russia); Dr. Manfred Lohmann (Ukraine); Elisio Macamo (Mozambique); Kalle Määttä (Finnland); Arne Mavcic (Slovenia); Martin Mayer (Senegal); Andrés MejíaVergnaud (Colombia); Irena Mladenova (Bulgaria); Fouzi Mourji (Maroc); Robert Nef (Swit- 
zerland); Marassulov Nurgalim (Kazakhstan); Joachim Nyemeck Binam (Ivory Coast); Dagmar Oberlies (Cambodia); Bojosi Otlhogile (Botswana); Dr. Hüseyin Özcan (Turkey); Krysztof Pawlowski (Poland); Nassef Perdomo (Dominican Republic); W. Petuelli (Haiti); Vytautas Piesliakas (Lithuania); Joseph Pini (France); Jean-Eric Rakotoarisoa (Madagaskar); Suri Ratnapala (Australia); Clara Elena Reales (Colombia); Boyd Reid (Trinidad \& Tobago); Jasmin Sadoun (Jordan); Rena Safaraliyeva (Azerbaijan); Jorge Silvero Salgueiro (Paraguay); Frieder von Sass (Tanzania); Anja Schoeller-Schletter (Paraguay); Bernhard Seliger (South Korea); John T. Shieh (Taiwan); Pavel Skoda (Slovakia); Eivind Smith (Norway); Dr. Solte (Bosnia and Hercegowina); Ricardo Ernesto Soto Barrios (Panama); Zane Spindler (Canada); Thomas Stauffer (Switzerland); Rigoberto Steward (Costa Rica); Neal Tate (Philippines); Jürgen Theres (Mauretanien); Joan Thompson (Bahamas); Sübidey Togan (Turkey); Mamadou Traoré (Ivory Cost); Xiomara Vallesteros (Nicaragua); Artur Victoria (Portugal); Veselin Vukotic (Montenegro); Wolfgang Weigel (Austria); Weliamuna (Sri Lanka); Dr. Jan Woischnik (Uruguay); Omri Yadlin (Israel).

\section{References}

Beck, Th., G. Clarke, A. Groff, Ph. Keefer, P. Walsh (2000), New tools and new tests in comparative political eco nomy: The Database of Political Institutions, Washington: The World Bank.

Besley, T. and A. Payne (2003); Judicial Accountability and Economic Policy Outcomes: Evidence from Employment Discrimination Charges, mimeo, June.

Brennan, G. and A. Hamlin (1994), A Revisionist View of the Separation of Powers, Journal of Theoretical Politics 6(3):345-368.

Brennan, G. and H. Kliemt (1994), Finite Lives and Social Institutions, Kyklos 47(4):551-571.

Chavez, R., J. Ferejohn and B. Weingast (2003); A Theory of the Politically Independent Judiciary, Paper presented at the annual meeting of the Am. Pol. Sc. Association, Philadelphia, August.

Congleton, R. (2003); Improving Democracy Through Constitutional Reform: Some Swedish Lessons, Dordrecht: Kluwer.

Dakolias, M. (1999), Court Performance Around the World: A Comparative Perspective, The Yale Human Rights \& Development Law Journal; downloadable from: http://www.yale.edu/yhrdli/vol02/dakolias maria article.htm (June22-03).

Duverger, M. (1980), A New Political System Model: Semi-Presidential Government, European Journal of Political Research 8(2):165-187.

Elazar, D. (1995), From Statism to Federalism: A Paradigm Shift, Publius 25(2):5-18.

Epstein, D. and Sh. O’Halloran (1999), Delegating Powers, Cambridge: Cambridge University Press.

Feld, L.P. and S. Voigt (2003), Economic Growth and Judicial Independence: Cross-Country Evidence using a new set of indicators, European Journal of Political Economy 19 (3): 497-527.

Ferejohn, J. and B. Weingast (1992); A Positive Theory of Statutory Interpretation, International Review of Law and Economics 12:263-79. 
Gely, R. and P. Spiller (1990); A Rational Theory of Supreme Court Statutory Decisions with Applications to the State Farm and Grove City Cases, Journal of Law, Economics, and Organization 6:263-300.

Ginsburg, T. (2002), Economic Analysis and the Design of Constitutional Courts, Theoretical Inquiries in Law 3(1): 4985.

Haan, J. de and J.E. Sturm (2000), On the Relationship between Economic Freedom and Economic Growth, European Journal of Political Economy 16: 215-241.

Hamilton, A., J. Madison and J. Jay (1788/1961), The Federalist Papers, with an introduction by C. Rossiter, New York: Mentor.

Hanssen, A. (2002); Is there a politically optimal level of judicial independence? Mimeo, June.

Harutyunayn, G. and A. Mavcic (1999), Constitutional Review and Its Development in the Modern World (A Comparative Constitutional Analysis); Yerevan and Ljubljana.

Hayek, F. (1960), The Constitution of Liberty, Chicago: University of Chicago Press.

Henisz, W. (2000), The Institutional Environment for Economic Growth, Economics and Politics 12, 1-31.

Heston, A., R. Summers and B. Aten (2001), Penn World Table, Version 6.0, Center for International Comparisons at the University of Pennsylvania (CICUP), December 2001.

Keefer, Ph. and D. Stasavage (2003), The Limits of Delegation, Veto Players, Central Bank Independence, and the Credibility of Monetary Policy, to appear in: American Political Science Review.

Ketcham, R. (ed./1986), The Anti-Federalist Papers and the Constitutional Convention Debates, New York: Mentor.

Landes, W. and R. Posner (1975), The Independent Judiciary in an Interest-Group Perspective, The Journal of Law and Economics, 18(3):875-911.

La Porta, R., F. Lopez-de-Silanes, A. Shleifer and R. Vishny (1999), The Quality of Government, Journal of Law, Economics and Organization 15: 222-279.

La Porta, R., F. López-de-Silanes, Ch. Pop-Eleches and A. Shleifer (2003), Judicial Checks and Balances, mimeo May.

Macey, J.R. (1992); Separated Powers and Positive Political Theory: The Tug of War Over Administrative Agencies, Georgetown Law Journal 80:671-703.

Majone, G. (1996). Temporal Consistency and Policy Credibility: Why Democracies Need Non-Majoritarian Institutions, European University Institute, Working Paper RSC No. 96/57.

Maskin, E. and J. Tirole (2001), The Politician and the Judge: Accountability in Government, Working Paper.

McCubbins, M., R. Noll and B. Weingast (1987); Administrative Procedures as Instruments of Political Control, Journal of Law, Economics, and Organization 3(2):243-77.

McCubbins, M., R. Noll and B. Weingast (1989); Structure and Process, Politics and Policy: Administrative Arrangements and the Political Control of Agencies, Virginia Law Review 75:431-82.

McCubbins, M. and T. Schwartz (1984); Congressional Oversight Overlooked: Police Patrols versus Fire Alarms, American Journal of Political Science 28:165-79.

Moe, T.M. (1990); Political Institutions: The Neglected Side of the Story, Journal of Law, Economics, and Organization 6:213-53.

Mueller, D. (1996), Constitutional Democracy, Oxford: Oxford University Press. 
Padovano, F., G. Sgarra, and N. Fiorino (2003), Judicial Branch, Checks and Balances and Political Accountability, Constitutional Political Economy 14(1):47-70.

Persson, T. and G. Tabellini (2003), The Economic Effects of Constitutions: What Do the Data Say?, Cambridge: MIT Press.

Persson, T., G. Roland, and G. Tabellini (1997), Separation of Powers and Political Accountability, Quarterly Journal of Economics 115:1163-1202.

Ramseyer, M. (1994), The Puzzling (In)dependence of Courts: A Comparative Approach, Journal of Legal Studies 23(2): 721-747.

Ramseyer, M. and E.B. Rasmusen (1997), Judicial Independence in a Civil Law Regime: The Evidence from Japan, Journal of Law, Economics and Organization 13(2): 259-286.

Ramseyer, M. and E.B. Rasmusen (1999), Why the Japanese Taxpayer Always Loses, Southern California Law Review 72(2/3): 571-595.

Ramseyer, M. and E.B. Rasmusen (2001a), Why Are Japanese Judges So Conservative in Politically Charged Cases?, American Political Science Review 95(2): 331-344.

Ramseyer, M. and E.B. Rasmusen (2001b), Why Is the Japanese Conviction Rate So High?, Journal of Legal Studies 30(1): 53-88.

Riker, W. (1964), Federalism: Origin, Operation, Significance, Boston: Little Brown.

Sartori, G. (1994), Comparative Constitutional Engineering, New York: New York University Press.

Toma, Eugenia (1991); Congressional Influence and the Supreme Court: The Budget as a Signaling Device, Journal of Legal Studies, 20:131-46.

Treisman, D. (2000), The Causes of Corruption: A Cross-National Study; Journal of Public Economics 76, 399-457.

Voigt, S. and E. Salzberger (2002), Choosing Not to Choose: When Politicians Choose to Delegate Powers, Kyklos 55(2):247-268.

Weingast, B. (1996), Rational Choice Perspectives on Institutions, in: Goodin, Robert E. and H. D. Klingemann (eds.), A New Handbook of Political Science, New York: Oxford University Press.

World Development Report (2002), Chapter 6: The Judicial System.

Zeppos, N.S. (1993); Deference to Political Decisionmakers and the Preferred Scope of Judicial Review, Northwestern University Law Review 88:296-371 


\section{CESifo Working Paper Series}

(for full list see www.cesifo.de)

1197 Hans Gersbach and Hans Haller, When Inefficiency Begets Efficiency, May 2004

1198 Saku Aura, Estate and Capital Gains Taxation: Efficiency and Political Economy Consideration, May 2004

1199 Sandra Waller and Jakob de Haan, Credibility and Transparency of Central Banks: New Results Based on Ifo's World Economicy Survey, May 2004

1200 Henk C. Kranendonk, Jan Bonenkamp, and Johan P. Verbruggen, A Leading Indicator for the Dutch Economy - Methodological and Empirical Revision of the CPB System, May 2004

1201 Michael Ehrmann, Firm Size and Monetary Policy Transmission - Evidence from German Business Survey Data, May 2004

1202 Thomas A. Knetsch, Evaluating the German Inventory Cycle - Using Data from the Ifo Business Survey, May 2004

1203 Stefan Mittnik and Peter Zadrozny, Forecasting Quarterly German GDP at Monthly Intervals Using Monthly IFO Business Conditions Data, May 2004

1204 Elmer Sterken, The Role of the IFO Business Climate Indicator and Asset Prices in German Monetary Policy, May 2004

1205 Jan Jacobs and Jan-Egbert Sturm, Do Ifo Indicators Help Explain Revisions in German Industrial Production?, May 2004

1206 Ulrich Woitek, Real Wages and Business Cycle Asymmetries, May 2004

1207 Burkhard Heer and Alfred Maußner, Computation of Business Cycle Models: A Comparison of Numerical Methods, June 2004

1208 Costas Hadjiyiannis, Panos Hatzipanayotou, and Michael S. Michael, Pollution and Capital Tax Competition within a Regional Block, June 2004

1209 Stephan Klasen and Thorsten Nestmann, Population, Population Density, and Technological Change, June 2004

1210 Wolfgang Ochel, Welfare Time Limits in the United States - Experiences with a New Welfare-to-Work Approach, June 2004

1211 Luis H. R. Alvarez and Erkki Koskela, Taxation and Rotation Age under Stochastic Forest Stand Value, June 2004 
1212 Bernard M. S. van Praag, The Connexion Between Old and New Approaches to Financial Satisfaction, June 2004

1213 Hendrik Hakenes and Martin Peitz, Selling Reputation When Going out of Business, June 2004

1214 Heikki Oksanen, Public Pensions in the National Accounts and Public Finance Targets, June 2004

1215 Ernst Fehr, Alexander Klein, and Klaus M. Schmidt, Contracts, Fairness, and Incentives, June 2004

1216 Amihai Glazer, Vesa Kanniainen, and Panu Poutvaara, Initial Luck, Status-Seeking and Snowballs Lead to Corporate Success and Failure, June 2004

1217 Bum J. Kim and Harris Schlesinger, Adverse Selection in an Insurance Market with Government-Guaranteed Subsistence Levels, June 2004

1218 Armin Falk, Charitable Giving as a Gift Exchange - Evidence from a Field Experiment, June 2004

1219 Rainer Niemann, Asymmetric Taxation and Cross-Border Investment Decisions, June 2004

1220 Christian Holzner, Volker Meier, and Martin Werding, Time Limits on Welfare Use under Involuntary Unemployment, June 2004

1221 Michiel Evers, Ruud A. de Mooij, and Herman R. J. Vollebergh, Tax Competition under Minimum Rates: The Case of European Diesel Excises, June 2004

1222 S. Brock Blomberg and Gregory D. Hess, How Much Does Violence Tax Trade?, June 2004

1223 Josse Delfgaauw and Robert Dur, Incentives and Workers' Motivation in the Public Sector, June 2004

1224 Paul De Grauwe and Cláudia Costa Storti, The Effects of Monetary Policy: A MetaAnalysis, June 2004

1225 Volker Grossmann, How to Promote R\&D-based Growth? Public Education Expenditure on Scientists and Engineers versus R\&D Subsidies, June 2004

1226 Bart Cockx and Jean Ries, The Exhaustion of Unemployment Benefits in Belgium. Does it Enhance the Probability of Employment?, June 2004

1227 Bertil Holmlund, Sickness Absence and Search Unemployment, June 2004

1228 Klaas J. Beniers and Robert Dur, Politicians' Motivation, Political Culture, and Electoral Competition, June 2004 
1229 M. Hashem Pesaran, General Diagnostic Tests for Cross Section Dependence in Panels, July 2004

1230 Wladimir Raymond, Pierre Mohnen, Franz Palm, and Sybrand Schim van der Loeff, An Empirically-Based Taxonomy of Dutch Manufacturing: Innovation Policy Implications, July 2004

1231 Stefan Homburg, A New Approach to Optimal Commodity Taxation, July 2004

1232 Lorenzo Cappellari and Stephen P. Jenkins, Modelling Low Pay Transition Probabilities, Accounting for Panel Attrition, Non-Response, and Initial Conditions, July 2004

1233 Cheng Hsiao and M. Hashem Pesaran, Random Coefficient Panel Data Models, July 2004

1234 Frederick van der Ploeg, The Welfare State, Redistribution and the Economy, Reciprocal Altruism, Consumer Rivalry and Second Best, July 2004

1235 Thomas Fuchs and Ludger Woessmann, What Accounts for International Differences in Student Performance? A Re-Examination Using PISA Data, July 2004

1236 Pascalis Raimondos-Møller and Alan D. Woodland, Measuring Tax Efficiency: A Tax Optimality Index, July 2004

1237 M. Hashem Pesaran, Davide Pettenuzzo, and Allan Timmermann, Forecasting Time Series Subject to Multiple Structural Breaks, July 2004

1238 Panu Poutvaara and Andreas Wagener, The Invisible Hand Plays Dice: Eventualities in Religious Markets, July 2004

1239 Eckhard Janeba, Moral Federalism, July 2004

1240 Robert S. Chirinko, Steven M. Fazzari, and Andrew P. Meyer, That Elusive Elasticity: A Long-Panel Approach to Estimating the Capital-Labor Substitution Elasticity, July 2004

1241 Hans Jarle Kind, Karen Helene Midelfart, Guttorm Schjelderup, Corporate Tax Systems, Multinational Enterprises, and Economic Integration, July 2004

1242 Vankatesh Bala and Ngo Van Long, International Trade and Cultural Diversity: A Model of Preference Selection, July 2004

1243 Wolfgang Eggert and Alfons J. Weichenrieder, On the Economics of Bottle Deposits, July 2004

1244 Sören Blomquist and Vidar Christiansen, Taxation and Heterogeneous Preferences, July 2004

1245 Rafael Lalive and Alois Stutzer, Approval of Equal Rights and Gender Differences in Well-Being, July 2004 
1246 Paolo M. Panteghini, Wide vs. Narrow Tax Bases under Optimal Investment Timing, July 2004

1247 Marika Karanassou, Hector Sala, and Dennis J. Snower, Unemployment in the European Union: Institutions, Prices, and Growth, July 2004

1248 Engin Dalgic and Ngo Van Long, Corrupt Local Government as Resource Farmers: The Helping Hand and the Grabbing Hand, July 2004

1249 Francesco Giavazzi and Guido Tabellini, Economic and Political Liberalizations, July 2004

1250 Yin-Wong Cheung and Jude Yuen, An Output Perspective on a Northeast Asia Currency Union, August 2004

1251 Ralf Elsas, Frank Heinemann, and Marcel Tyrell, Multiple but Asymmetric Bank Financing: The Case of Relationship Lending, August 2004

1252 Steinar Holden, Wage Formation under Low Inflation, August 2004

1253 Ngo Van Long and Gerhard Sorger, Insecure Property Rights and Growth: The Roles of Appropriation Costs, Wealth Effects, and Heterogeneity, August 2004

1254 Klaus Wälde and Pia Weiß, International Competition, Slim Firms and Wage Inequality, August 2004

1255 Jeremy S. S. Edwards and Alfons J. Weichenrieder, How Weak is the Weakest-Link Principle? On the Measurement of Firm Owners' Control Rights, August 2004

1256 Guido Tabellini, The Role of the State in Economic Development, August 2004

1257 François Larmande and Jean-Pierre Ponssard, EVA and the Controllability-congruence Trade-off: An Empirical Investigation, August 2004

1258 Vesa Kanniainen and Jenni Pääkkönen, Anonymous Money, Moral Sentiments and Welfare, August 2004

1259 Panu Poutvaara and Andreas Wagener, Why is the Public Sector More Labor-Intensive? A Distortionary Tax Argument, August 2004

1260 Lars P. Feld and Stefan Voigt, Making Judges Independent - Some Proposals Regarding the Judiciary, August 2004 